\title{
Differences in plant cover and species composition of semiarid grassland communities of central Mexico and its effects on net ecosystem exchange
}

\author{
J. Delgado-Balbuena ${ }^{1}$, J. T. Arredondo ${ }^{1}$, H. W. Loescher ${ }^{2,3}$, E. Huber-Sannwald ${ }^{1}$, G. Chavez-Aguilar ${ }^{1}$, \\ M. Luna-Luna ${ }^{4}$, and R. Barretero-Hernandez ${ }^{4}$ \\ ${ }^{1}$ División de Ciencias Ambientales, Instituto Potosino de Investigación Científica y Tecnológica A. C. (IPICYT), San Luís \\ Potosí, 78216, Mexico \\ ${ }^{2}$ Science Department, National Ecological Observatory Network, Boulder, CO 80301, USA \\ ${ }^{3}$ Institute of Alpine and Arctic Research, University of Colorado, Boulder, CO 80303, USA \\ ${ }^{4}$ Instituto Nacional de Investigaciones Forestales, Agrícolas y Pecuarias, Km. 10 Carr. Ojuelos-Lagos de Moreno, Jalisco, \\ Mexico
}

Correspondence to: J. T. Arredondo (tulio@ipicyt.edu.mx)

Received: 16 October 2012 - Published in Biogeosciences Discuss.: 4 December 2012

Revised: 1 June 2013 - Accepted: 11 June 2013 - Published: 12 July 2013

\begin{abstract}
Changes in land use across the semiarid grasslands of northern Mexico have driven a decline of plant cover and alteration of plant species composition. A number of different plant communities have resulted from these changes. Their implications, however, on the carbon (C) cycle and regional carbon balance are still poorly understood. Here, we examined the effects of plant cover loss and changes in species composition on net ecosystem $\mathrm{CO}_{2}$ exchange (NEE) and their biotic and abiotic controls. NEE was measured in five representative plant community types within a semiarid grassland by temporarily enclosing the entire aboveground ecosystem using a chamber method (i.e., geodesic dome). Sites included an oat crop (crop), a moderately grazed grassland (moderate grazing), a 28 yr-old grazing exclosure (exclosure), an overgrazed site with low perennial grass cover (overgrazed), and an overgrazed site presenting shrub encroachment (shrub encroachment). For natural vegetation, rates of standardized daytime NEE for sites with a high plant cover (exclosure and moderate grazing) were similar $(P>0.05)$ as compared to sites with low plant cover (overgrazed and shrub encroachment). However, yearly total nighttime NEE (carbon loss) was more than double $(P<0.05)$ for sites with high plant cover compared to sites with low cover, resulting to slight $\mathrm{C}$ sinks for the low plant cover sites, and neutral or sources for the high plant cover sites as accounted by daytime and nighttime NEE annual bal-
\end{abstract}

ance. Differences in plant cover and its associated biomass defined the sensitivity to environmental controls. Thus, daytime NEE in low plant cover sites reached light compensation points at lower photosynthetic photon flux density than those from high plant cover sites. Differences in species composition did not influence NEE rates even though there were transient or permanent changes in C3 vs. C4 functional groups. Our results allowed the detection of the large variability and contribution of different plant communities to regional $\mathrm{C}$ balance in patchy landscapes. Identification of the role of landscape patches in the regional $\mathrm{C}$ balance as either sinks or sources may provide tools allowing land use management strategies that could favor $\mathrm{C}$ uptake in patchy landscapes.

\section{Introduction}

Semiarid grasslands cover $18 \%$ of global lands (Lal, 2004), with a large fraction being either overgrazed or converted to cropland (Hart, 2008). Conversion of natural grasslands to other land uses primarily causes a loss in plant cover and changes in species composition (Chapin et al., 2008), resulting in alterations of both community structure and ecosystem functions (Belsky, 1992; Noy-Meir, 1995; Houghton and Goodale, 2004), which may turn grasslands into potential sources of carbon to the atmosphere (DeFries et al., 1999). 
Grazing by domestic livestock can vary in intensity and frequency, often exceeding the functional capacity of grasslands to recover from overuse, leading to a number of changes: a loss in perennial grass cover and root biomass (Medina-Roldán et al., 2008), an increase in subordinate and non-palatable species (Milchunas and Lauenroth, 1993; Aguado-Santacruz and Garcia-Moya, 1998), and a reduction of fuel and therefore the incidence of natural fires. Collectively, these changes lead to shrub encroachment (Brown and Archer, 1999; Knapp et al., 1999).

Conversion of grasslands to crop fields also contributes to the loss of soil organic matter and seasonal loss of plant cover (inter-cropping periods) and an enhancement of soil respiration through common tillage practices (Huggins et al., 1998; Alluvione et al., 2009). Land use change (e.g., land conversion and overgrazing) contributes directly to patchy grassland landscapes that result from changes in plant communities and also contributes towards large uncertainties in carbon exchange from these heterogeneous landscapes (Levy et al., 2004).

Net ecosystem exchange for $\mathrm{CO}_{2}$ (NEE) is the sum of gross ecosystem exchange and total ecosystem respiration (Loescher et al., 2006a) and is controlled by biotic (e.g., leaf area index - LAI) and abiotic factors (e.g., photosynthetic photon flux density - PPFD, temperature, precipitation) (Chapin et al., 2002). These biotic and abiotic controls can influence NEE rates non-linearly and incorporate complex feedbacks that differ depending on ecosystem type (Chapin et al., 2008; Lindroth et al., 2008) and disturbance regime (cf. Starr et al., 2013).

Current knowledge on the biotic controls on NEE contributed by the different plant communities from grassland landscapes suggests that the overall carbon uptake capacity of landscapes may decrease as a result of reduced LAI or the substitution of key plant species by less suited ones (e.g., substitution of key $\mathrm{C}_{4}$ by $\mathrm{C}_{3}$ species, Novick et al., 2004; Wohlfahrt et al., 2008a). Losses in vegetation cover may also alter the energy balance of ecosystems through an increase in albedo and associated changes in the hydrological cycle (Chapin et al., 2008; Medina-Roldan et al., 2007). Exposed bare soil contributes to carbon losses through increased soil respiration, wind and water erosion. Larger respiration rates may occur seasonally under these conditions through a combination of higher soil moisture (e.g., during the rain season) and greater soil warming in sites with low plant cover (Xue-Fa et al., 2006). At large spatial scales, changes in ecosystem functioning across a landscape can influence local and regional climate through complex biosphere-atmosphere feedback mechanisms: (i) emission of greenhouse gases, (ii) modifications in energy budgets related to alterations in latent and sensible heat fluxes, (iii) changes in emitted longwave radiation, (iv) changes in soil moisture, (v) changes in aerosol emissions, and (vi) changes in surface roughness (Chapin et al., 2008).
In the southernmost part of the grassland biome in Mexico, the geographic subprovince Llanos de Ojuelos, overgrazing, natural fire suppression and conversion to rainfed agriculture have contributed to a patchy grassland landscape in $70 \%$ of its $12000 \mathrm{~km}^{2}$ (Huber-Sannwald, 2002; Velázquez et al., 2002). Reported ranges of natural plant cover in these grasslands varied from a maximum of $35-38 \%$ to a low of $~ 5 \%$ (Aguado-Santacruz and García-Moya, 1998), with equivalent aboveground biomass accumulation variability ranging from 1500 to $180 \mathrm{~kg} \mathrm{ha}^{-1}$, respectively. Because overgrazing causes the key native species Bouteloua gracilis to be replaced by subordinate grass species, the capacity of soil water recharge is reduced (Medina-Roldán et al., 2007). Overgrazing has also been shown to result in a $20 \%$ loss in soil organic carbon content due to $25 \%$ loss in plant cover (Medina-Roldán et al., 2008). Also, the replacement of Bouteloua gracilis by perennial shrubs (e.g., Isocoma veneta) and non-native herbs (e.g., Asphodelus fistulosus) contributes to decreased plant productivity (AguadoSantacruz and García-Moya, 1998; Medina-Roldán et al., 2007). Changes in species composition, on the other hand, could also potentially enhance carbon uptake with the establishment of perennial woody species that may display higher annual carbon uptake rates (Scott et al., 2006). These studies suggest complex interactions among community composition, community structure, hydrological processes, and regional carbon dynamics, all related to landscape patch composition.

For the patchy semiarid grassland landscapes of Llanos de Ojuelos, we hypothesized that reductions in plant cover will cause an overall decline in net carbon uptake as a result of less perennial vegetation and lower production of LAI and aboveground biomass $\left(\mathrm{H}_{1}\right)$. To examine the influence of environmental controls on NEE for each land use type, we hypothesize that a decreased plant cover (and related reduction of aboveground biomass) will increase the sensitivity of key ecosystem processes governing productivity (i.e., photosynthesis and respiration) to environmental factors: air temperature $\left(T_{\mathrm{a}}\right)$, PPFD, and soil water content (SWC). Therefore, NEE should reach maximum rates (maximum $\mathrm{C}$ uptake$\mathrm{NEE}_{\text {daytime }}$ and $\mathrm{C}$ efflux-NEE $\mathrm{N}_{\text {nighttime }}$ ) faster and sooner at sites with low plant cover relative to sites with high plant cover $\left(\mathrm{H}_{2}\right)$. Finally, we hypothesize that NEE rates will not differ among plant communities with similar amounts of plant cover but different species composition $\left(\mathrm{H}_{3}\right)$. To test these hypotheses, NEE fluxes of the most common plant communities found in a patchy landscape of semiarid grassland were measured. Equally, we examined these NEE fluxes and their relationship to site-specific biotic (LAI) and abiotic $\left(T_{\mathrm{a}}\right.$, PPFD, and SWC) factors affecting their rates. 


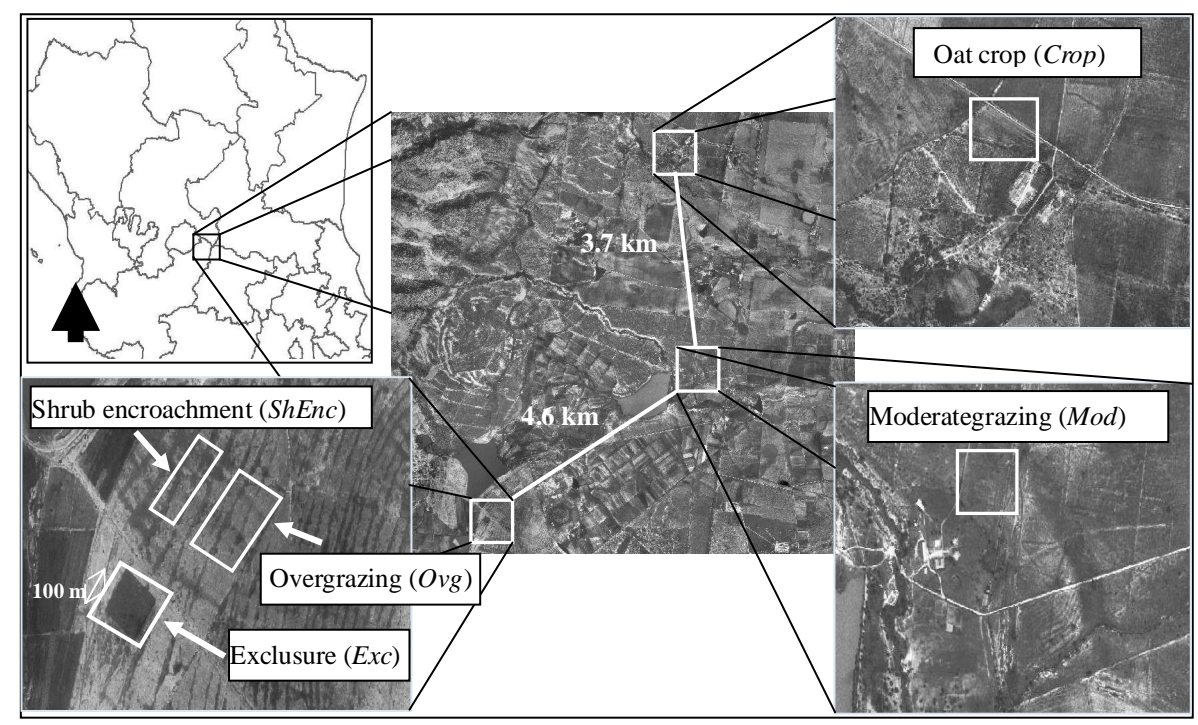

Fig. 1. Location of the study sites in Llanos de Ojuelos, Jalisco in central Mexico.

\section{Materials and methods}

\subsection{Site description}

The semiarid grasslands in Mexico (North American graminetum, Aguado-Santacruz and García-Moya, 1998) belong to the shortgrass steppe ecosystem extending from the North American midwest in the north to the subprovince Llanos de Ojuelos in northeast Jalisco in the south. This biome follows a narrow N-S strip along the Sierra Madre Occidental within the Chihuahuan Desert. The vegetation is dominated by grasses with Bouteloua gracilis H. B. K. Lag ex Steud. (blue grama) as the dominant species, forming near mono-specific stands (García-Moya and Villa, 1977). Native grasslands are one of the most threatened ecosystems in Mexico, because intensive grazing by domestic livestock and land conversion to rainfed agriculture (Velázquez et al., 2002; Rzedowski, 2006) have created a patchy landscape exhibiting large diversity in plant cover and species composition (Riojas-Lopez and Mellink, 2005). The region presents a semiarid climate with mean annual precipitation of $424 \pm 11 \mathrm{~mm}$ (last $30 \mathrm{yr}$ ) distributed mainly between June and September, followed by 6 to 9 dry months. Winter rain accounts for $<5 \%$ of total annual precipitation (García, 2003). Mean annual temperatures are $17.5 \pm 0.5^{\circ} \mathrm{C}$ $(\mu \pm 1 \mathrm{SE})$, with mean monthly temperatures ranging between $2.2^{\circ} \mathrm{C}$ for the coldest and $26.8^{\circ} \mathrm{C}$ for the warmest months (dataset from weather station of Sitio Experimental Vaquerias, INIFAP). The topography is characterized by valleys and gentle rolling hills. The two dominant soil types are haplic Xerosols (associated with Lithosols and eutric Planosols) and haplic Phaeozems (associated with Lithosols) (Aguado-Santacruz, 1993). Soils are silty clay and sandy loams, shallow with average depth ranging between 0.3 and
$0.5 \mathrm{~m}$ with a cemented layer of tepetate (Aguado-Santacruz, 1993) (COTECOCA, 1979).

We selected five contrasting plant communities that have resulted from different grazing regimes and agriculture disturbance. All sites had similar soil type, topography and landscape position (Fig. 1). Plant cover at the sites was classified as either high (maximum reported for the region 35-38\% of soil covered by vegetation; Table 1 , Aguado-Santacruz and García-Moya, 1998) or low plant cover $(<10 \%$ of vegetation cover; Table 1). Sites also represented two conditions in terms of species composition: one in which the key native species, $B$. gracilis, was still dominant (independent of plant cover), while the other presented either subordinate grasses, subshrubs or exotic species as dominant species. There were five site types examined. (i) One was a moderate grazing site (moderate grazing) that was a recovered grassland to tillage and overgrazing $(50 \mathrm{yr})$, currently under moderate grazing regime and prescribed burning ( $4 \mathrm{yr}$ previous to the study). Moderate grazing was defined by two vegetation traits; one related to the grazing intensity level allowing only $50 \%$ of standing biomass to be removed by livestock every year. This grazing intensity regime was estimated by first assessing aboveground biomass annual productivity (dry matter basis) to estimate its carrying capacity based on the dry matter demand of livestock (an animal unit $=$ cow of $450 \mathrm{~kg}$ ). With this information, a stocking rate is estimated at a desired grazing intensity (in our case 50\%). The desired grazing intensity has been defined from physiological studies examining the recovery of root growth following aboveground defoliation (Crider, 1955; Richards and Caldwell, 1985). The grazing regimes included here were not imposed for this particular study but observed under current use at each site. The other trait was related to the proportion of soil plant cover that in the case of high plant cover was above $30 \%$ (Table 1). 
Table 1. Shortgrass steppe characteristics of the study sites in the sub-province Llanos de Ojuelos, located in the northeast part of Jalisco State, Mexico.

\begin{tabular}{|c|c|c|c|c|c|}
\hline Site & Land use change & $\begin{array}{c}\text { Aboveground } \\
\text { biomass } \\
\left(\mathrm{kg} \text { dry matter } \mathrm{ha}^{-1}\right)\end{array}$ & $\begin{array}{c}\text { Plant } \\
\text { cover }(\%)\end{array}$ & $\begin{array}{l}\text { Species } \\
\text { composition } \\
\text { (dominant } \\
\text { species) }\end{array}$ & Coordinates \\
\hline Exclosure & $\begin{array}{l}28 \text { yr non-grazed, } \\
\text { exclosure to } \\
\text { domestic cattle }\end{array}$ & $800-1200$ & $35-40$ & $\begin{array}{l}\text { Bouteloua } \\
\text { gracilis }\end{array}$ & $\begin{array}{l}21^{\circ} 45^{\prime} 32.42^{\prime \prime} \mathrm{N} \\
101^{\circ} 38^{\prime} 32.29^{\prime \prime} \mathrm{W}\end{array}$ \\
\hline $\begin{array}{l}\text { Moderate } \\
\text { Grazing }\end{array}$ & $\begin{array}{l}\text { Site recovered from } \\
\text { heavy grazing; burned } \\
4 \mathrm{yr} \text { previous the study }\end{array}$ & $800-1200$ & $35-40$ & $\begin{array}{l}\text { Bouteloua } \\
\text { gracilis, } \\
\text { Muhlenbergia } \\
\text { rigida }\end{array}$ & $\begin{array}{l}21^{\circ} 46^{\prime} 52.25^{\prime \prime} \mathrm{N} \\
101^{\circ} 36^{\prime} 29.56^{\prime \prime} \mathrm{W}\end{array}$ \\
\hline Overgrazing & 70 yr overgrazed & $80-240$ & $5-10$ & $\begin{array}{l}\text { Bouteloua } \\
\text { gracilis, } \\
\text { abundant soil } \\
\text { biological crust }\end{array}$ & $\begin{array}{l}21^{\circ} 45^{\prime} 36.36^{\prime \prime} \mathrm{N} \\
101^{\circ} 38^{\prime} 20.58^{\prime \prime} \mathrm{W}\end{array}$ \\
\hline $\begin{array}{l}\text { Shrub } \\
\text { Encroachment }\end{array}$ & 70 yr overgrazed & 440 & $5-10$ & $\begin{array}{l}\text { Isocoma } \\
\text { veneta, } \\
\text { Asphodelus } \\
\text { fistulosus }\end{array}$ & $\begin{array}{l}21^{\circ} 45^{\prime} 41.17^{\prime \prime} \mathrm{N} \\
101^{\circ} 38^{\prime} 24.85^{\prime \prime} \mathrm{W}\end{array}$ \\
\hline Crop & Rainfed agriculture & $1500-2500^{*}$ & Variable & Avena sativa & $\begin{array}{l}21^{\circ} 49^{\prime} 9.53^{\prime \prime} \mathrm{N} \\
101^{\circ} 36^{\prime} 38.50^{\prime \prime} \mathrm{W}\end{array}$ \\
\hline
\end{tabular}

* indicates the maximum standing crop at the final harvest in contrast to year-round productivity.

Even though this site exhibited a high plant cover, the native grass species $B$. gracilis has been largely replaced by subordinate native grass species (30-40\% replacement of the total abundance) including Muhlenbergia rigida (Kunth) Trin., B. scorpioides Lag., B. hirsuta Lag., Aristida spp. (ii) The second site was a 30 yr-old cattle exclosure site (exclosure) characterized by a high plant cover dominated by $B$. gracilis (> $80 \%$ abundance). (iii) The third site was an overgrazed site (overgrazed) with a low plant cover (5-8\%) with $\mathrm{B}$. gracilis as the most abundant species. In this site, grazing intensity may overpass $90 \%$ of aboveground biomass removal by cattle because of the lack of management plans and use of regulation policies in communally owned land. (iv) The fourth site was a shrub encroachment site (shrub encroachment) that was also an overgrazed site with low plant cover $(<8 \%)$ having co-dominance with a native shrub Isocoma veneta (Kunth) Greene and an exotic Mediterranean perennial herb Asphodelus fistulosus L; finally, (v) the fifth site was a crop site (crop), previously a shortgrass steppe converted to rain-fed agriculture field to produce oat (Avena sativa $\mathrm{L}$ ). The oat crop covers the soil for approximately four months during summer. Biomass removal from grazing or additions from dung were not quantified. Site characteristics can be found in Tables 1 and 2 .

To initially select the sites, we used the line intercept method (Canfield, 1941) to assess basal grass cover and species composition. Three to four $20 \mathrm{~m}$ transects were sampled per site. Once the sites were chosen and the plots installed, we used digital photography and image analysis (Sig-
maScan Pro v. 5.0, Systat Software Inc., San Jose, CA) to determine both the proportion of canopy cover per plot and the abundance of each species with respect to the total number of species (Table 2).

\subsection{Measurement of NEE}

A large static chamber method (Arnone and Obrist, 2003; from now on "dome") was used to directly and nondestructively quantify NEE from these five study sites. The dome had a $4.2 \mathrm{~m}$ base diameter (Shelter Systems Inc., Menlo Park, CA, USA) with an internal volume of $16.4 \mathrm{~m}^{3}$ covering a ground area of $12.25 \mathrm{~m}^{2}$. When measurements were carried out, the dome was sealed to permanent iron bases that were knifed $3 \mathrm{~cm}$ into the ground. The iron bases were installed and allowed to equilibrate with the ground for two months prior to the beginning of the study. Iron bases protruded an additional $3 \mathrm{~cm}$ above the ground for attachment purposes, defining the area of measurement. At each of the five sites, six plots (replicates) were randomly established for a total of 30 plots used in this study. Even within a site, plots differed in the proportion of species and plant cover, still maintaining the general features of the vegetation. Since each of these plots responded $\left(\mathrm{CO}_{2}\right.$ fluxes) independently to each of the controlling factors, we considered these as independent replicates.

Prior to each measurement, two air fans were positioned $\sim 0.5 \mathrm{ma}$ a.g.l. on opposite sides of the plot to mix air inside the dome (model 3306, Mytek International Inc., Bonita, 
Table 2. Vegetation cover characteristics at the five experimental sites, classified according to photosynthetic metabolism of dominant functional groups.

\begin{tabular}{|c|c|c|c|c|}
\hline Site & $\begin{array}{l}\text { Photosynthetic } \\
\text { metabolism }\end{array}$ & $\begin{array}{l}\text { Canopy cover } \\
(\%) \pm \mathrm{SE}\end{array}$ & $\begin{array}{l}\text { LAI } \\
\left(\mathrm{m}^{2} \mathrm{~m}^{-2}\right) \pm \mathrm{SE}\end{array}$ & $\begin{array}{l}\text { Standing dead biomass } \\
\left(\mathrm{kg} \mathrm{ha}^{-1}\right) \pm \mathrm{SE}\end{array}$ \\
\hline Exclosure & $\begin{array}{l}\mathrm{C}_{3} \\
\mathrm{C}_{4}\end{array}$ & $\begin{array}{l}5.82 \pm 1.68 \\
81.46 \pm 3.07\end{array}$ & $\begin{array}{l}0.022 \pm 0.002 \\
0.58 \pm 0.05\end{array}$ & $1500.33 \pm 116.66$ \\
\hline $\begin{array}{l}\text { Moderate } \\
\text { grazing }\end{array}$ & $\begin{array}{l}\mathrm{C}_{3} \\
\mathrm{C}_{4}\end{array}$ & $\begin{array}{l}5.15 \pm 1.15 \\
81.07 \pm 3.61\end{array}$ & $\begin{array}{l}0.063 \pm 0.027 \\
0.56 \pm 0.13\end{array}$ & $2393.27 \pm 222.7$ \\
\hline Overgrazing & $\begin{array}{l}\mathrm{C}_{3} \\
\mathrm{C}_{4}\end{array}$ & $23.23 \pm 1.3$ & $0.17 \pm 0.02$ & $82.72 \pm 6.58$ \\
\hline $\begin{array}{l}\text { Shrub } \\
\text { encroachment }\end{array}$ & $\begin{array}{l}\mathrm{C}_{3} \\
\mathrm{C}_{4}\end{array}$ & $\begin{array}{l}16.51 \pm 1.46 \\
9.18 \pm 3.47\end{array}$ & $\begin{array}{l}0.21 \pm 0.05 \\
0.034 \pm 0.014\end{array}$ & $146.1 \pm 25.41$ \\
\hline Crop & $\begin{array}{l}\mathrm{C}_{3} \\
\mathrm{C}_{4}\end{array}$ & $19.6 \pm 1.33$ & $0.53 \pm 0.07$ & 0 \\
\hline
\end{tabular}

CA). One fan was oriented horizontally, while the other was vertically oriented; both had a flow rate of $54.3 \mathrm{~m}^{3} \mathrm{~h}^{-1}$. Carbon dioxide and $\mathrm{H}_{2} \mathrm{O}$ concentrations, and atmospheric pressure outside the dome, were measured using an open-path infrared $\mathrm{CO}_{2} / \mathrm{H}_{2} \mathrm{O}$ gas analyzer (IRGA; Li-7500, LI-COR Inc., Lincoln, NE) located in the center of the plot and also mounted $0.5 \mathrm{~m}$ a.g.l. Available pressure data may not reflect dome pressure (the sensor was outside the dome in the circuit box). Still for this large static chamber, changes in pressure by overpressurization that could lead to inhibition of soil respiration fluxes (Davidson et al., 2002) (when, for instance, the chamber is positioned on the iron base) are not expected (which would be expected by open-flow gas exchange systems) because of the large volume: area ratios. Large volume : area ratios also allow small changes of the gas density, avoiding molecular diffusion across the soil surface driven by a gas concentration gradient (Livingston and Hutchinson, 1995). The observed linear trend for $\left[\mathrm{CO}_{2}\right]$ and $\left[\mathrm{H}_{2} \mathrm{O}\right]$ in most measurements is evidence that no changes in pressure occurred inside the dome. Intermittent pressure changes during the 2-3 min monitoring periods would have been observed as erratic $\left[\mathrm{CO}_{2}\right]$ and $\left[\mathrm{H}_{2} \mathrm{O}\right]$ concentrations.

Even though there are several methods that can be used to measure NEE (Livingston and Hutchinson, 1995), the dome covers enough area to measure both the representative plant communities and their physical structure, allowing us to directly and consistently measure NEE from these five plant communities with minimal disturbance. Moreover, this approach has been shown to estimate similar fluxes as those obtained through the eddy covariance method (Wohlfahrt et al., 2008b), further validating this methodology.

Meteorological sensors were used inside and outside the dome during each measurement: PPFD (PARLITE, Kipp and Zonen, Delft, the Netherlands), and $T_{\mathrm{a}}$ sensors (PRT type, RTD-810, Omega Engineering Inc., Stamford, CT) with a linearizer (OM5-IP4-N100-C, Omega Engineering Inc., Stamford, CT). Additionally, SWC (Mini Trase, SoilMoisture Equipment Corp., Santa Barbara, CA) measure- ments were also carried out inside and outside the dome plot. Two pairs of sensors were moved from plot to plot together with the IRGA sensor, so PPFD and $T_{\mathrm{a}}$ records correspond to the time period when we made the NEE measurements. Both the PPFD and $T_{\mathrm{a}}$ sensor were located at the canopy height of monitored vegetation (from soil level in overgrazed site to $40 \mathrm{~cm}$ in the oat site). Sensors inside the dome were located close to the center, whereas sensors outside were located around $5 \mathrm{~m}$ away from the dome. In the case of SWC, we inserted permanent steel (TDR) rods to $15 \mathrm{~cm}$ depth, since this corresponded with most of the root system distribution. In this case, readings on each plot (inside and outside) were carried out at noon once during the day.

Data from all sensors were acquired with a data logger (CR1000, Campbell Scientific Inc., Logan, UT, USA) at a frequency of $1 \mathrm{~Hz}$, providing the temporal resolution to record the rate of change in $\mathrm{CO}_{2}$ concentration. These meteorological measurements were used to determine functional relationships between NEE and abiotic environment, and to determine potential dome effects.

At each site, NEE measurements were made monthly from October 2008 to September 2009. Each measurement campaign included four sampling periods per site throughout the day at 08:00, 12:00, 16:00 and 20:00 solar time LT, allowing us to determine diurnal NEE time series. Because of the length of each sampling period, the distance between sites, and the need for one full day to sample a single site, each monthly campaign consisted of five consecutive days of measurements (one day per site). During each individual flux measurement, the dome was placed on a plot for $\sim 120$ s during daytime and $\sim 180$ s during nighttime. Data were recorded immediately after the geodesic dome was sealed to the iron base. However, in the case of NEE calculations, usable data were obtained after the first 20 s, i.e., once a constant rate of $\left[\mathrm{CO}_{2}\right]$ change inside the dome was observed. Beginning on March 2009, parallel and following daytime measurements, the dome was covered with a dark "cloak" to block light (PPFD was dropped 
to $<30 \mu$ mol photons $\mathrm{m}^{-2} \mathrm{~s}^{-1}$, Harpole et al., 2007). In this way, it was possible to measure ecosystem respiration $(\mathrm{Re})$ across a wider range of temperatures. Inherent to the use of the cloak to cover the dome and in our ability to model nighttime Re using daytime Re measurements is the influence of photosynthesis on respiration rates through the mechanism of carbohydrate supply and demand (Dewar et al., 1999; Whitehead et al., 2004). The influence of photosynthesis on ecosystem respiration can last for hours, days and even for weeks (Vargas et al., 2011). Thus, in addition to the effects on ecosystem respiration by mean photosynthesis rate during daytime periods, photosynthesis can even affect nighttime respiration. This effect is consistently accounted for by our method by incorporating nighttime Re measurement (instead of neglecting it) to allow bias correction. However, since there has been neither previous discussion nor quantitative estimations on photoassimilate availability influencing ecosystem respiration fluxes, it is difficult in our study to obtain an estimation of the bias. In conclusion, we support the contention that the dome cover method used in this study provides a smaller bias for nighttime ecosystem respiration estimates than conventional soil respiration chambers that can underestimate fluxes because of their limitations to include the large ecosystem spatial heterogeneity.

Calculations of dome NEE are based on the rate of change of $\left[\mathrm{CO}_{2}\right]$ for day and night conditions. The dry mole fraction of $\mathrm{CO}_{2}\left(C^{\prime}\right)$ from the IRGA was estimated by

$C^{\prime}=\frac{C}{1-\frac{W}{10^{3} \mu \mathrm{mol}}}$,

where $C$ and $W$ refer to the measured mole fraction of $\mathrm{CO}_{2}$ $\left(\mu \mathrm{mol} \mathrm{mol}{ }^{-1}\right.$ ) and $\mathrm{H}_{2} \mathrm{O}\left(\mathrm{mmol} \mathrm{mol}^{-1}\right)$, respectively. Then, the measured $\mathrm{CO}_{2}$ was scaled to the dome ground area, and the rate of concentration change to estimate NEE according to

$\mathrm{NEE}=\frac{V \bar{P}(1000-\bar{W})}{R S(\bar{T}+273.15)} \cdot \frac{\partial C^{\prime}}{\partial t}$,

where, NEE refers to the $\mathrm{CO}_{2}$ flux $\left(\mathrm{molm}^{-2} \mathrm{~s}^{-1}\right), V$ the dome volume $\left(\mathrm{m}^{3}\right), P$ the average atmospheric pressure $(\mathrm{kPa})$ inside the dome, $R$ the ideal gas constant $\left(8.314 \mathrm{~J} \mathrm{~mol}^{-1} \mathrm{~K}^{-1}\right), S$ the surface area covered by the dome $\left(\mathrm{m}^{2}\right)$, while the analytic solution for $\partial C^{\prime} / \partial t$ is the slope of least square linear regression of $C^{\prime}$ for each measurement period per plot and time of day, and the overbar is the time average during the measurement period (i.e., either 100 or $160 \mathrm{~s}$ of constant rate of $\left[\mathrm{CO}_{2}\right]$ change (Jasoni et al., 2005)). Just the linear portion of the regression after $\left[\mathrm{CO}_{2}\right]$ stabilization was used to calculate the rate of $\left[\mathrm{CO}_{2}\right]$ change. Here, we use the micrometeorological convention where negative values indicate uptake of carbon by the ecosystem.

Linear and non-linear models were fitted to describe the relationship between NEE and biotic and abiotic drivers. Daytime and nighttime NEE rates were analyzed separately because processes governing these rates and their controls differ during day and night.

The functional relationship of daytime NEE fluxes to PPFD was estimated by fitting a rectangular hyperbola function (Ruimy et al., 1995):

$\mathrm{NEE}_{\text {daytime }}=\frac{\alpha \cdot \mathrm{PPFD} \cdot A_{\max }}{\alpha \cdot \mathrm{PPFD}+A_{\max }}+R_{\mathrm{d}}$,

where $\alpha$ is the apparent quantum yield ( $\mu \mathrm{mol} \mathrm{CO} 2 \mathrm{~m}^{-2} \mathrm{~s}^{-1} \mu \mathrm{mol}^{-1}$ photons), PPFD ( $\mu$ mol photons $\mathrm{m}^{-2} \mathrm{~s}^{-1}$ ), $A_{\max }$ the maximum assimilation rate at light saturation conditions $\left(\mu \mathrm{mol} \mathrm{CO} \mathrm{CO}^{-2} \mathrm{~s}^{-1}\right)$, and $R_{\mathrm{d}}$ represents daytime respiration $\left(\mu \mathrm{mol} \mathrm{CO} \mathrm{Cm}^{-2} \mathrm{~s}^{-1}\right)$. Equation (3) is typically calculated assuming infinite PPFD values, which often return unrealistic values of $A_{\max }$. Hence, we also estimated Eq. (3) by constraining the maximum PPFD value to $2000 \mu \mathrm{mol} \mathrm{m} \mathrm{m}^{-2} \mathrm{~s}^{-1}$ to estimate a new, more realistic $A_{\max }$ value $=A_{2000}$. Including air temperature did not improve the variability explained by the $\mathrm{NEE}_{\text {daytime }}$ model. We did try several light-response models reported in the literature (e.g., Gilmanov et al., 2010), some of them including temperature; however, the hyperbolic model (Eq. 3) showed the best fit.

In the period from March to May, an exponential function was used to describe the relationship between $\mathrm{NEE}_{\text {daytime }}$ and air temperatures. In this period the semiarid tropical grassland is going through the senescent phenological stage because of annual drought. Therefore, no active photosynthetic leaves are observed (LAI $=0)$. Hence, recorded fluxes correspond to ecosystem respiration $\left(R_{\mathrm{e}}\right)$ that only responds to temperature.

$$
\begin{aligned}
& \mathrm{NEE}_{\text {daytime }}=r_{0} \cdot \exp \left(k_{T} \cdot T_{\mathrm{a}}\right), \\
& Q_{10}=\exp \left(10 \cdot k_{T}\right),
\end{aligned}
$$

where $r_{0}$ and $k_{T}$ are empirical coefficients; $r_{0}$ is the ecosystem respiration rate at $T_{\mathrm{a}}=0\left(\mu \mathrm{mol} \mathrm{CO} \mathrm{m}^{-2} \mathrm{~s}^{-1}\right)$, and $k_{T}$ is the coefficient of temperature response $\left({ }^{\circ} \mathrm{C}^{-1}\right)$. Equation (4b) is a $Q_{10}$ approach (the increase in respiration rate with a $10^{\circ} \mathrm{C}$ increase in $T_{\mathrm{a}}$ ) to estimate the $\mathrm{NEE}_{\text {daytime }}$ response to temperature.

Two linear, first-order regressions were used to determine the effect of SWC and LAI on NEE daytime, such that

$$
\begin{aligned}
& \mathrm{NEE}_{\text {daytime }}=y_{0}+a \cdot \mathrm{SWC}, \\
& \mathrm{NEE}_{\text {daytime }}=y_{1}+b \cdot \mathrm{LAI},
\end{aligned}
$$

where $y_{i}(i=0,1$, or 2$)$ is the statistical $y$ axis intercept, and $a$ and $b$ are empirical coefficients; whereas $\mathrm{NEE}_{\text {nighttime, }}$ SWC and $T_{\mathrm{a}}$ were fitted to an exponential power function:

$\mathrm{NEE}_{\text {nighttime }}=a e^{\left(b \cdot T_{\mathrm{a}}\right)} \cdot \mathrm{SWC}^{c}$,

where $a, b$, and $c$ are empirical coefficients, $T_{\mathrm{a}}$ air temperature, and SWC soil water content. 
Since we did not record soil temperature in this study, we used air temperature to model both $\mathrm{NEE}_{\text {daytime }}$ (from March to May) and $\mathrm{NEE}_{\text {nighttime. However, according to previous }}$ studies carried out in grasslands, $\mathrm{NEE}_{\text {nighttime }}$ shows a closer correlation to air temperature than to soil temperature (Lasslop et al., 2012).

\subsection{Calculation of daily NEE}

Daytime $\mathrm{CO}_{2}$ fluxes were calculated as follows: to calculate continuous fluxes for each daylight measurement period (hereafter integrated daytime NEE), the rectangular hyperbolic model (Eq. 3) for each site/month under the diurnal cycle was applied. Continuous PPFD data for each month were estimated online with the "clear sky calculator" for quantum sensors website (http://clearskycalculator.com/quantumsensor.htm). Same latitude $\left(21.7^{\circ} \mathrm{N}\right)$ and longitude $\left(-101.6^{\circ}\right)$, relative humidity $(30 \%)$, and altitude ( $2200 \mathrm{~m}$ a.s.l.) were assumed in the model for the five sites. As the model calculates PPFD at ideal clear sky conditions, daytime NEE was also calculated as ideal NEE rates with no clouds for each site.

Nighttime $\mathrm{CO}_{2}$ fluxes were calculated as follows: integrated NEE at night was calculated by the exponential model (Eq. 6). NEE data of both the 20:00 to 23:00 sampling periods and daytime on dark conditions (dome coat) were used to model the cycle of NEE at night. Continuous air temperature data (as an average per month) were obtained from a weather station near the moderate grazing site, while for soil water content we used averages measured at each site during the sampling time. Modeling nighttime NEE was carried out only for nighttime hours (no daylight, $\mathrm{PPFD}=0$ ).

Annual NEE rates were calculated as follows: (i) integrating $\mathrm{NEE}_{\text {daytime }}$ under the diurnal cycle $\left(\mathrm{NEE}_{\text {daytime }}\right.$ in response to PPFD), (ii) integrating $\mathrm{NEE}_{\text {nighttime }}$ for nighttime cycles ( $\mathrm{NEE}_{\text {nighttime }}$ in response to $T_{\mathrm{a}}$ and $\mathrm{SWC}$ ), (iii) adding $\mathrm{NEE}_{\text {nighttime }}$ to $\mathrm{NEE}_{\text {daytime }}$ to estimate monthly NEE rate ( $\mathrm{g} \mathrm{C} \mathrm{m}^{-2} \mathrm{~d}^{-1}$ ), and (iv) averaging monthly balances to estimate an annual NEE rate. Additionally, annual cumulative NEE was also calculated by integrating the monthly daily NEE rate $\left(\mathrm{NEE}_{\text {daytime }}-\mathrm{NEE}_{\text {nighttime }}\right)$ over each respective month, and adding afterwards monthly totals together for an annual NEE estimate. NEE rates and climate were assumed to be representative for the entire month with this approach. As stated previously, $\mathrm{NEE}_{\text {daytime }}$ was calculated under ideal PPFD conditions that do not represent the natural variation of incoming PPFD over a plant canopy, due to the absence of clouds and a high relative humidity. Then, calculated annual $\mathrm{NEE}_{\text {daytime }}$ is likely overestimated, and should be considered as an indication of the maximum carbon uptake of each ecosystem type under ideal daylight conditions.

Within each site and sampling period, aboveground biomass and LAI were estimated using six $0.25 \mathrm{~m}^{2}$ quadrants, positioned next to and outside the dome bases. The only exception was at the shrub encroachment site where the size of the quadrant was increased to $1 \mathrm{~m}^{2}$ to include all vegetation and vegetation structural elements. Live aboveground biomass was completely removed from the quadrants and stored in sealed plastic bags containing humidity pads to maintain the leaves at saturated condition until analysis. Collected live leaves were passed through a leaf area meter (Li-3000C, LI-COR Inc., Lincoln, NE) to estimate LAI.

\subsection{Statistical analyses}

All NEE data were normally distributed on a diurnal time series. Classification variables included site (exclosure, moderate grazing, overgrazing, shrub encroachment, crop). A one-way ANOVA was used to compare integrated daytime and nighttime NEE means among sites $(n=10$, sites $=5$, $\alpha=0.05$ ). Analyses were also made from daytime and nighttime flux values $\left(\mathrm{NEE}_{\text {daytime }}\right.$ and $\left.\mathrm{NEE}_{\text {nighttime }}\right)$ individually, because both fluxes were subjected to different environmental drivers. The bootstrapping method (Efron and Tibshirani, 1993) was used to estimate the $95 \%$ bias corrected confidence intervals of integrated daytime and nighttime NEE. Resampling of observed PPFD $\times$ NEE, and $T_{\mathrm{a}} \times \mathrm{SWC} \times \mathrm{NEE}$ dataset (of equal size to the observed dataset) for each site/month were constructed by randomly sampling with replacement from the original dataset. A new light response curve (Eq. 3) was fitted, and then NEE was integrated for each resampled dataset. This was done with 2000 iterations to obtain 2000 integrated NEE values, from which a mean and confidence interval (95\%) of NEE were computed. The same method was used to calculated means and confidence intervals of nighttime NEE, but using Eq. (7) as the regression model for each bootstrapped resampling.

For bootstrapping, PPFD and $T_{\mathrm{a}}$ used in regressions were modeled data, while SWC was measured data. This allowed us to homogenize environmental conditions (PPFD and $T_{\mathrm{a}}$ ), which were independent of the characteristics of plant communities. However, SWC was maintained as a site-specific variable, because we assumed that the effects were dependent on plant cover, species composition, root systems, and soil characteristics.

Confidence intervals (CIs, 95\%) were used to compare the integrated daytime and nighttime NEE by month, examining CIs overlapping among adjusted $\mathrm{NEE}_{\text {daytime, }}$, and $\mathrm{NEE}_{\text {nighttime }}$ curves of the five sites. These CIs were also used as an estimated uncertainty, which was propagated according to the law of propagation of uncertainty (ISO, 2008) for cumulative NEE. In this case, uncertainty coverage of $95 \%$ was assumed.

Relationships between the response variable (NEE) and environmental factors (PPFD, $T_{\mathrm{av}}, \mathrm{SWC}$, and LAI) were examined with linear and non-linear regression analysis. To determine the amount of variability in $\mathrm{NEE}_{\text {daytime }}$ and $\mathrm{NEE}_{\text {nighttime }}$ explained by seasonal abiotic drivers, daily fluxes (integrated $\mathrm{NEE}_{\text {daytime }}$ and $\mathrm{NEE}_{\text {nighttime}}$ ) were used as a dependent variable. All regressions, ANOVA, and 
bootstrapping analyses were performed using SAS 8.0 for Windows (SAS Institute Inc., Cary, NC, USA).

\section{Results}

\subsection{Abiotic environment}

Annual cumulative precipitation during the study period was representative of the past $30 \mathrm{yr}$ regional average (Fig. 2a), with $442 \mathrm{~mm} \mathrm{yr}^{-1}$ recorded in both 2008 and 2009. For the long-term average, July had the highest monthly precipitation annually; however, 2008 and 2009 deviated from this overall pattern. For 2008, August received $230 \mathrm{~mm}$, which was twice as much as the long-term average for that month, and represented $52 \%$ of the total annual precipitation. For 2009, September received $206 \mathrm{~mm}$, the wettest month of this year, representing $47 \%$ of the total annual precipitation (Fig. 2a).

Average PPFD values among sites were recorded with larger divergences among sites during the rainy season because of the spatial variability in cloud cover (Fig. 2b). Winter and spring (November to May) had the lowest SWC $(<9 \%)$ for all sites coinciding with the long-term trends in precipitation (Fig. 2c). In the wet months, the exclosure site had the highest SWC in October 2008, and July and August $2009(19.0 \pm 0.66 \%, 29.3 \pm 1.07 \%$, and $35.9 \pm 0.66 \%$, respectively; Fig. 2c), followed by moderate grazing site $(16.28 \pm 0.66 \%$, and $26.3 \pm 0.66 \%$ for October 2008 and June 2009, respectively). The overgrazed, shrub encroachment and crop sites had the overall lowest SWC (10-15\%), suggesting limitations to recharge and retain soil water after rain events. Peak $T_{\mathrm{a}}$ inside the dome of $30^{\circ} \mathrm{C}$ was recorded from February to May (Fig. 2d).

\subsection{LAI dynamics}

Seasonal changes in LAI were recorded at all sites, with maximum values occurring between June and October (Fig. 2e). The two sites with the highest plant cover, the exclosure and moderate grazing sites, had significantly higher LAI during maximum leaf-out than found at overgrazed and shrub encroachment sites $(p<0.05$, Fig. 2e). Although their overall phenological development coincided both in time and in magnitude, LAI in the moderate grazing site was $0.15 \mathrm{~m}^{2} \mathrm{~m}^{-2}$ larger than LAI in the exclosure site (Fig. 2e). Equally, the shrub encroachment and overgrazed sites maximum LAI $=0.23 \pm 0.008 \mathrm{~m}^{2} \mathrm{~m}^{-2}$ were 80,75 and $65 \%$ less than those recorded for the crop, moderate grazing and exclosure sites, respectively. In contrast, the crop site had the highest LAI of $0.94 \pm 0.23$ and $1.24 \pm 0.30$, for August and September, respectively. Because the crop site underwent tillage, seeding, and harvest following typical agronomic management practices, its LAI was close to zero during fallow months from November to May.
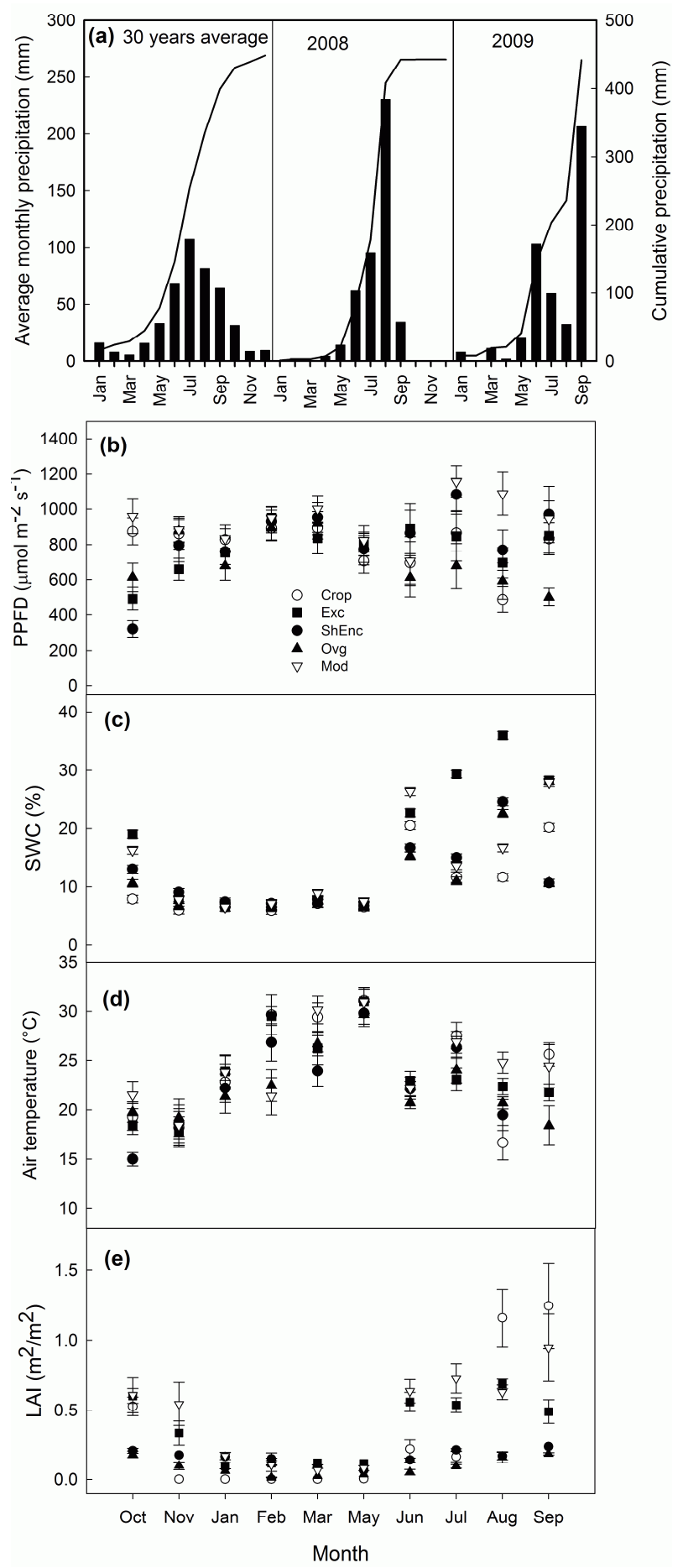

Fig. 2. (a) Average monthly and annual cumulative precipitation over a $30 \mathrm{yr}$ period (left panel) and during the study period October 2008-July 2009 (central and right panels) in Los Llanos de Ojuelos, Mexico. Monthly time series from October 2008 to September 2009 depicting (b) PPFD, (c) SWC, (d) $T_{\mathrm{a}}$, and (e) LAI at five contrasting land use types in the shortgrass steppe in central Mexico. All points represent the mean $\pm 1 \mathrm{SE}$. Acronyms stand for Crop=oat crop, $\mathrm{Exc}=$ exclosure, ShEnc $=$ shrub encroachment, Ovg $=$ overgrazing and $\mathrm{Mod}=$ moderate grazing. 
Table 3. Summary of ANOVA table for daily $\mathrm{NEE}_{\text {daytime }}, \mathrm{NEE}_{\text {nighttime}}$, and $\mathrm{NEE}_{\text {balance }}$ contrasting land use change types in the shortgrass steppe in central Mexico. Factors included in the model term are site (exclosure, shrub encroachment, overgrazing, moderate grazing, crop), time of day (TOD; 08:00, 12:00, 16:00 and 20:00 LT), date (October, November, January, February, March, May, June, July, August and September).

\begin{tabular}{lrrrr|r|rrrrrr|rrrr}
\hline & \multicolumn{4}{c|}{ Daytime } & \multicolumn{4}{c}{ Nighttime } & \multicolumn{4}{c}{ Balance } \\
\hline Source & df & SS & MS & $F$ & $p$ & df & SS & MS & $F$ & $p$ & df & SS & MS & $F$ & $p$ \\
Model & 4 & 2.73 & 0.68 & 0.54 & 0.71 & 4 & 3.46 & 0.87 & 5.41 & $<0.01$ & 4 & 1.95 & 0.49 & 0.50 & 0.74 \\
Error & 45 & 57.06 & 1.27 & & & 45 & 7.20 & 0.16 & & & 45 & 44.14 & 0.98 & \\
Total & 49 & 59.79 & & & & 49 & 10.66 & & & & 49 & 46.08 & & \\
corrected & & & & & & & & & & & & & & \\
\hline
\end{tabular}

$\mathrm{df}=$ degrees of freedom, $\mathrm{SS}=$ sums of squares, $\mathrm{MS}=$ mean square.

\subsection{Net ecosystem $\mathrm{CO}_{2}$ exchange}

Overall, no significant differences in daytime flux were detected with ANOVA among the ten months $(p>0.05$, Figs. 3a and 4, Table 3). Still, negative fluxes (carbon uptake) were recorded for most sites during the growing season (October-November 2008, and June-September 2009, Fig. 3a), while neutral or positive (carbon release) $\mathrm{NEE}_{\text {daytime }}$ was observed during the drought period (December to May). Crop was the only site showing positive $\mathrm{NEE}_{\text {daytime }}$ flux for November, when there was no plant cover. Still, in July the crop cover showed a positive C flux, but in August it changed to the largest $\mathrm{NEE}_{\text {daytime }}$ uptake $\left(-6.08\right.$, asymmetric s.e. $\left.+4.82,-0.94 \mathrm{~g} \mathrm{C} \mathrm{m}^{-2} \mathrm{~d}^{-1}\right)$ coinciding with maximum leaf-out and grain-filling stages. These fluxes were 2 times larger compared to grassland sites with highest plant cover. In both the exclosure and the moderate grazing sites, $\mathrm{NEE}_{\text {daytime }}$ was negative in six of ten recorded months. Sites with the lowest plant cover (overgrazing and shrub encroachment) showed for at least three months lower $\mathrm{C}$ uptake as compared to any of the other sites during the same period.

Maximum $\mathrm{NEE}_{\text {nighttime }}$ was observed in the growing season and was almost zero during the dry season. However, $\mathrm{NEE}_{\text {nighttime }}$ rates from overgrazed and shrub encroachment sites were much lower than fluxes from moderate grazing and exclosure sites, particularly during the wet months. $\mathrm{NEE}_{\text {nighttime }}$ fluxes in the overgrazed site were the smallest throughout the year ( 0.1 to $0.45 \mathrm{~g} \mathrm{C} \mathrm{m}^{-2} \mathrm{~d}^{-1}$ ), resulting in significantly lower annual instantaneous $\mathrm{NEE}_{\text {nighttime }}$ rates at the end of ten months $(P<0.05$, Figs. $3 \mathrm{~b}$ and 4 , Table 3), whereas NEE $_{\text {nighttime }}$ fluxes in exclosure and moderate grazing sites were more than double compared to sites with low plant cover. The oat crop site maintained intermediate $\mathrm{NEE}_{\text {nighttime }}$ rates that were significantly higher than the overgrazed site fluxes.

We estimated annual rates of productivity; however, data for both December and April were not included due to sampling problems. Daytime and nighttime NEE rates were between -0.34 and $0.43 \mathrm{~g} \mathrm{C} \mathrm{m}^{-2} \mathrm{~d}^{-1}$, respectively, for winter months (November to March), with net diurnal rates around

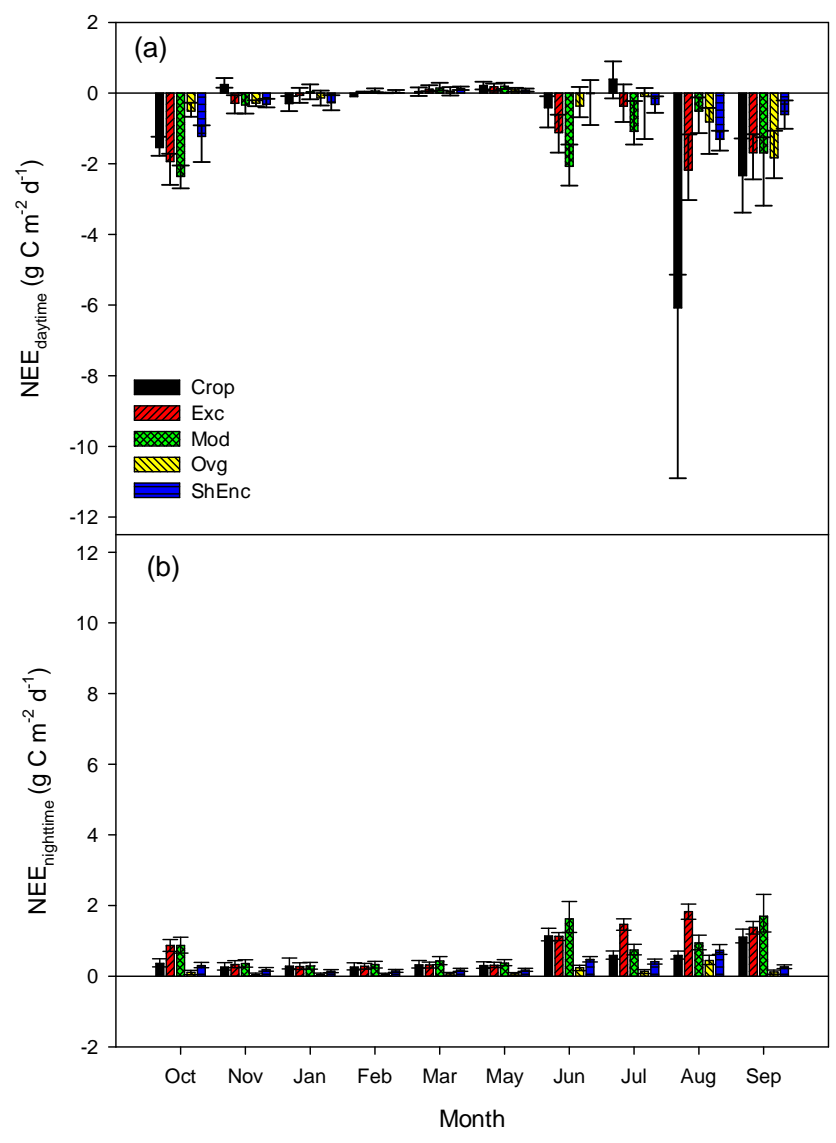

Fig. 3. Daily daytime (a) and nighttime (b) NEE (mean \pm 1 CI) at five sites with contrasting land use types in the shortgrass steppe from central Mexico, recorded from October 2008 to September 2009. For explanation of acronyms, please refer to Fig. 2

$0 \mu \mathrm{mol} \mathrm{m} \mathrm{m}^{-2} \mathrm{~s}^{-1}$. Based on the similar conditions, we assumed that monthly NEE rates for the two missing months were also carbon neutral allowing us to estimate an annual C balance.

Interpreting the annual average of $\mathrm{CO}_{2}$ fluxes $\left(\overline{\mathrm{NEE}}_{\text {daytime }}+\mathrm{NEE}_{\text {nighttime }} ;\right.$ overbar denotes annual average $)$ for the crop, overgrazed, and shrub encroachment sites, the 

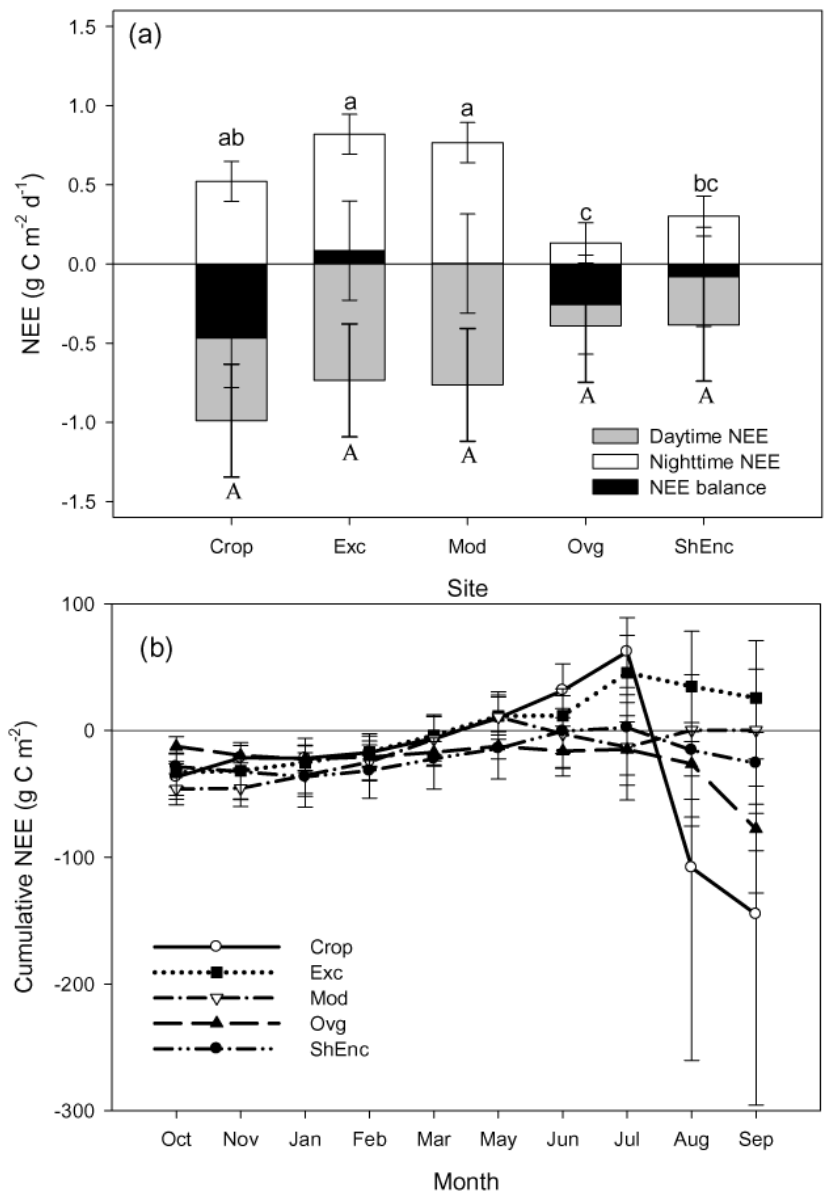

Fig. 4. (a) Average rates of net NEE (mean $\pm 1 \mathrm{SE}$ ) in the shortgrass steppe in central Mexico associated with five different land use types. Different letters on both the top and bottom of bars indicate significant differences among sites $(P<0.05$, capital letters indicate daytime differences, whereas lowercase letters refer to nighttime differences in fluxes). (b) Cumulative NEE in the five sites, recorded from October 2008 to September 2009. Bars denote the combined standard uncertainty for each cumulative NEE. For explanation of acronyms, refer to Fig. 2.

$\mathrm{C}$ balance suggests that these sites functioned as carbon sinks (net $\mathrm{CO}_{2}$ uptake of $-0.47 \pm 0.31,-0.26 \pm 0.31$, and $-0.08 \pm 0.31 \mathrm{~g} \mathrm{C} \mathrm{m}^{-2} \mathrm{~d}^{-1}$, respectively, Fig. $4 \mathrm{a}, \mathrm{b}$, equivalent to $-145.1_{-150.6}^{+50.33},-77.6_{-48.1}^{+45.3}$, and $-25.8_{-39.5}^{+24.3} \mathrm{~g} \mathrm{C} \mathrm{m}^{-2}$ $\mathrm{y}^{-1}$, respectively, Fig. 4a, b). In contrast, the exclosure behaved as a source (net $\mathrm{CO}_{2}$ loss of $0.085 \pm 0.31 \mathrm{~g} \mathrm{C} \mathrm{m}^{-2} \mathrm{~d}^{-1}$, or $25.7_{-48.1}^{+45.3} \mathrm{~g} \mathrm{C} \mathrm{m}^{-2} \mathrm{y}^{-1}$, Fig. 4a, b), whereas the moderate grazing site was carbon-neutral $\left(0.003 \pm 0.31 \mu \mathrm{mol} \mathrm{m}{ }^{-2} \mathrm{~s}^{-1}\right.$, or $0.26_{-58.3}^{+0.48} \mathrm{~g} \mathrm{C} \mathrm{m}^{-2} \mathrm{y}^{-1}$, Fig. $\left.4 \mathrm{a}, \mathrm{b}\right)$.

\subsection{Daily and seasonal drivers of $\mathrm{CO}_{2}$ fluxes}

Both abiotic and biotic controls on NEE changed across seasons and phenological stages. Thus, there were five dominant patterns that emerged from this study: (i) PPFD con- trol of $\mathrm{CO}_{2}$ uptake acting on a daily timescale; (ii) $T_{\mathrm{a}}$ also controlled $R_{\mathrm{e}}$ on a daily bases; (iii) SWC and LAI exerted seasonal control on uptake and efflux, strongly suggesting the phenological feedback between leaf activity and SWC as main controls of the annual $\mathrm{C}$ balance in this biome; (iv) legacy effects of the land impacting on the carbon balance (i.e., exclosure, agriculture); and (v) rates of uptake and efflux were highest at the more intensely managed site (i.e., crop), where the time of crop cover dictates the annual carbon balance.

For all sites, PPFD was the main factor explaining $\mathrm{NEE}_{\text {daytime }}$ at daily timescales, with plant communities displaying two principal responses: (i) $\mathrm{NEE}_{\text {daytime }}$ reached an asymptote with PPFD saturation, and (ii) $\mathrm{NEE}_{\text {daytime }}$ responded almost linearly to increases in PPFD. For instance, in October 2008, the $\mathrm{NEE}_{\text {daytime }}$ light response of exclosure and moderate grazing sites was linear and increased well beyond PPFD values of $1000 \mu \mathrm{mol} \mathrm{m}^{-2} \mathrm{~s}^{-1}$ (Fig. 5a), whereas for June and July 2009, $\mathrm{NEE}_{\text {daytime }}$ light response curves were hyperbolic (Fig. 5c, d). In general, sites with higher plant cover reached $\mathrm{NEE}_{\text {daytime }}$ saturation at higher PPFD than those with lower plant cover (Fig. 5a, c, d, e).

For all sites except the crop (there was no plant cover), $T_{\mathrm{a}}$ was a better predictor for $\mathrm{NEE}_{\text {daytime }}$ fluxes during the dry season (March to May, Eq. 5, Fig. 6a, b) compared to the wet season, where no $T_{\mathrm{a}}$ relationship was detected. In general, sites showed relatively small changes in $\mathrm{NEE}_{\text {daytime }}$ in responses to increases in $T_{\mathrm{a}}$ ( $k_{T}$ coefficients from exponential function $<0.1$ ) when $T_{\mathrm{a}}<30^{\circ} \mathrm{C}$, but $\mathrm{NEE}_{\text {daytime }}$ rates increased after $30^{\circ} \mathrm{C}$. In particular, the shrub encroachment site stood out from the other sites with the highest $k_{T}$ ( $>0.14$ ) during the three dry months (Fig. 6). This result was further supported by $Q_{10}$ values for the same site, of 4.2, 4.3 and 4.4 for February, March and May, respectively (no crop present), compared to $Q_{10}$ rates of 2.5 observed from the other sites (data not shown). With more plant cover, $\mathrm{NEE}_{\text {daytime }}$ rates increased with higher $T_{\mathrm{a}}$, with no significant difference $(p>0.05)$ due to species composition.

Over the course of the year, the main control on $\mathrm{NEE}_{\text {daytime }}$ was SWC and LAI, explaining $>47 \%$ and $>67 \%$ of $\mathrm{NEE}_{\text {daytime }}$ variation, respectively (Eqs. 5a, b, Table 4). Drivers for $\mathrm{NEE}_{\text {daytime }}$ exerted different effects on sites with high plant cover in comparison to sites with low plant cover. Thus, while both SWC and LAI explained $>56 \%$ (linear relationship) of $\mathrm{NEE}_{\text {daytime variation in sites }}$ with high cover, the $\mathrm{NEE}_{\text {daytime }}$ of overgrazed and crop sites was described by a quadratic and linear model with LAI respectively. On the other hand, seasonal $\mathrm{NEE}_{\text {daytime }}$ variation in shrub encroachment site was explained by SWC, whereas the crop NEE was better explained by LAI (Eq. 5, Table 4). Although data did not allow a homogeneity of slopes test, the moderate grazing site showed almost twice the assimilation rate per unit of water stored in soil $\left(0.1 \pm 0.02 \mathrm{~g} \mathrm{C} \mathrm{m}^{-2} \mathrm{~d}^{-1}\right.$ per $\left.\% \mathrm{SWC}^{-1}\right)$ than the exclosure and shrub encroachment sites $\left(0.0636 \pm 0.017\right.$ and $0.062 \pm 0.025 \mathrm{~g} \mathrm{C} \mathrm{m}^{-2} \mathrm{~d}^{-1}$ 


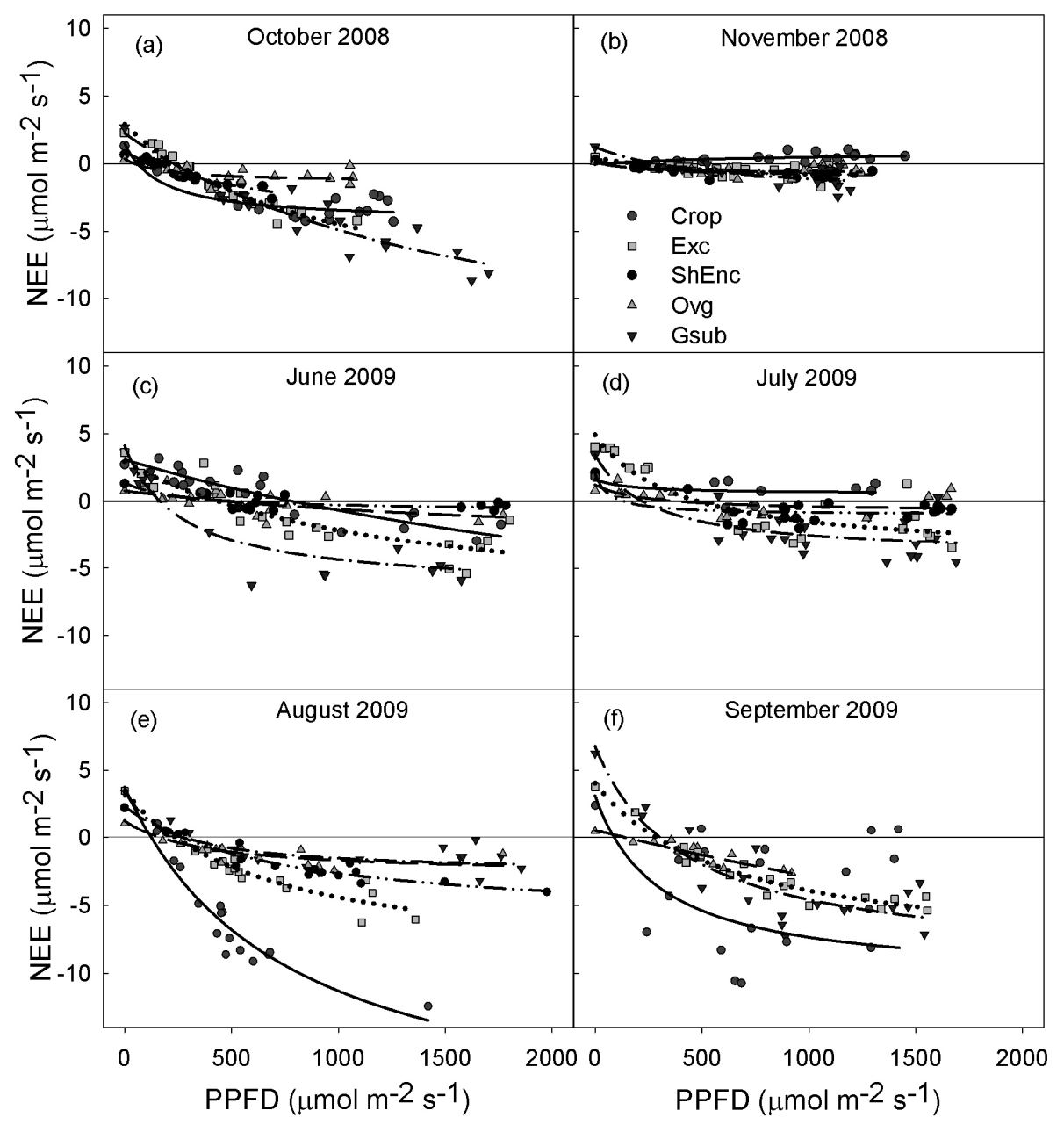

Fig. 5. Relationships between observed daytime NEE and PPFD fitted to a rectangular hyperbola function (Eq. 3) for five contrasting land use types in the shortgrass steppe in central Mexico. Line symbols correspond to the following: $\cdots$ Exc, $-\cdot-$ Mod, --- Ovg,,$-\cdot-$ ShEnc, and Crop. For explanations of acronyms, refer to Fig. 2.

per $\% \mathrm{SWC}^{-1}$, respectively). Overall, $\mathrm{NEE}_{\text {nighttime was con- }}$ trolled by SWC and $T_{\mathrm{a}}$, but in this case it was fitted to an exponential-power model (Eq. 6) that explained $>44 \%$ of its variation (Table 4). Although temperature was a main driver for daily $\mathrm{NEE}_{\text {nighttime, }}$ its relationship was controlled seasonally by SWC.

Empirical coefficients $a$ and $b$ of the first term of Eq. (6) were contrasted among the two categories of plant cover. Thus, sites with low plant cover showed smaller $a$ parameter than high cover sites, but in contrast they showed bigger $b$ parameters. This values for $a$ and $b$ indicate that low plant cover sites produced the smallest nighttime fluxes.

\subsection{Differences due to species composition}

We did not measure productivity from individual species within a site. Instead, we assumed that the suite of plant species at a particular site acted collectively for an integrated ecosystem response, i.e., NEE (Loescher et al., 2006b). How- ever, because we showed that plant cover (amount and phenology) is a key control on productivity, we tested for any species control $\left(\mathrm{H}_{3}\right)$ using sites with similar plant cover but differing in species composition. One group included the exclosure and the moderate grazing sites, in which the key species $B$. gracilis for the moderate grazing site has been largely replaced by other subordinate native grasses. The second group (i.e., low plant cover) included overgrazed and shrub encroachment sites in which subordinate grasses, subshrubs or non-native grasses and herbs were as abundant as the key species. Comparison of shrub encroachment and overgrazed sites revealed no differences in $\mathrm{NEE}_{\text {daytime }}$ and $\mathrm{NEE}_{\text {nighttime }}(p>0.05$, Fig. 4). Similar patterns for $\mathrm{NEE}_{\text {daytime }}$ and $\mathrm{NEE}_{\text {nighttime were estimated between the two }}$ high plant cover sites. Thus, there was no clear effect of vegetation species composition on fluxes. 


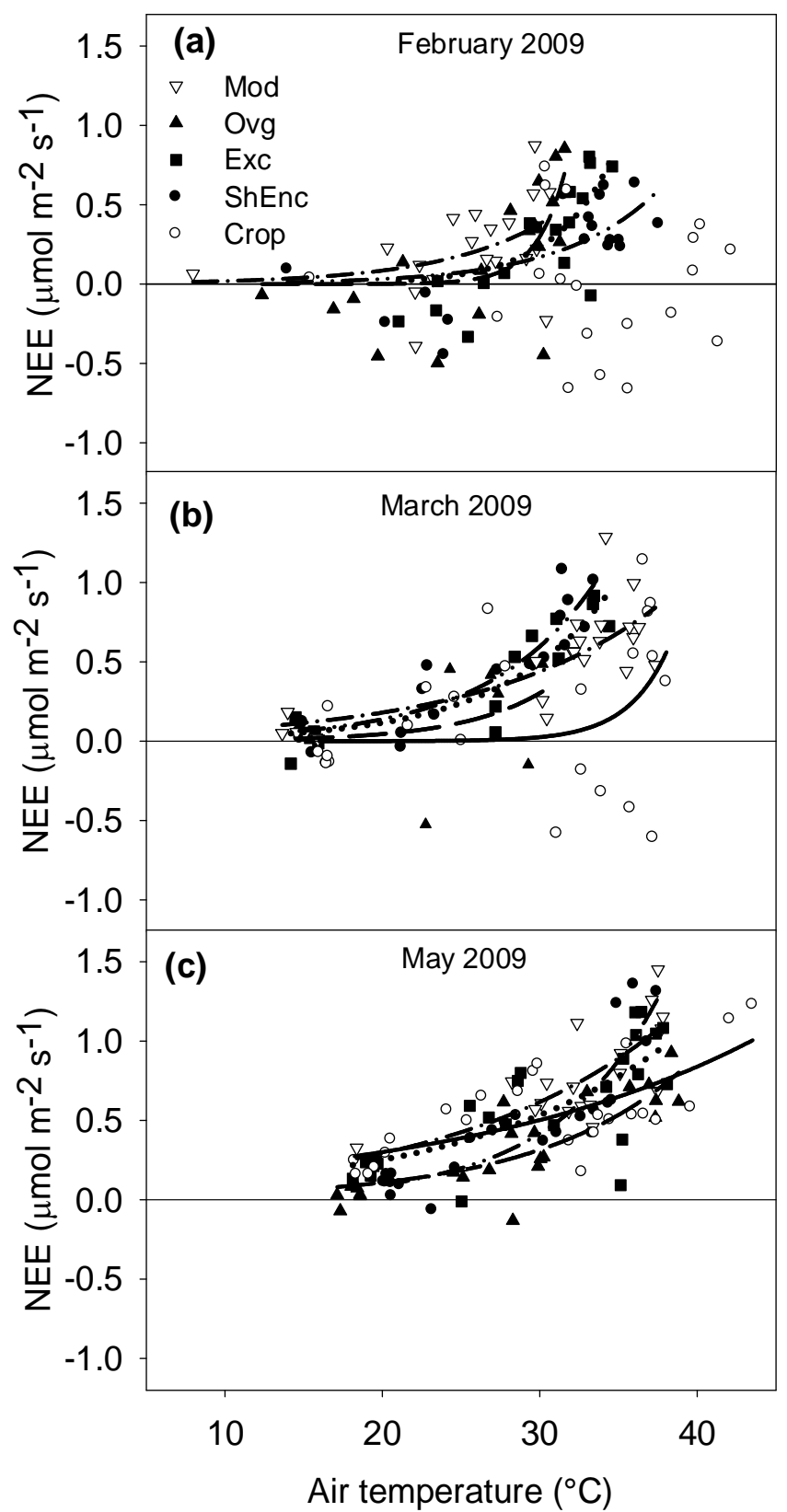

Fig. 6. Exponential relationships between daytime NEE and $T_{\mathrm{a}}$ for February (a), March (b) and May (c) in five contrasting land use types in the shortgrass steppe in central Mexico. All regressions were statistically significant at $P<0.05$, with exception of the oat crop site in March. Also for March, the Ovg site curve is missing because there were not enough data. Daytime NEE resulted in a positive flux $\left(R_{\mathrm{e}}\right)$ in this period because vegetation was senescent and LAI was $\sim 0$; therefore, PPFD did not exerted control on NEE. Line symbols correspond to the following: $\cdots$ Exc, $-\cdot-$ Mod, -Ovg, $-\cdot \cdot-$ ShEnc, and — Crop. For explanation of abbreviations, refer to Fig. 2.

\section{Discussion}

\subsection{Effects of plant cover on NEE}

In this study, differences in plant cover from different sites arising from historic changes in land use showed no contrasting rates of NEE. Testing $\mathrm{H}_{1}$ (reductions in plant cover will cause a decline in net carbon uptake), sites with high plant cover (moderate grazing and exclosure) did not show larger rates for carbon uptake $\left(\mathrm{NEE}_{\text {daytime }}\right.$, Figs. 3,4$)$ than sites with less plant cover (overgrazed and shrub encroachment). Moderate grazing and exclosure also had proportionally larger biomass and consequently greater ecosystem respiration rates (e.g., maintenance costs) than the low plant cover sites. For instance, the larger proportion of $R_{\mathrm{e}}$ observed for the exclosure and moderate grazing sites relative to daytime uptake was the main factor contributing to the exclosure having a net positive annual carbon balance (net loss of $\mathrm{CO}_{2}, R_{\mathrm{e}}>\mathrm{NEE}_{\text {daytime }}$, Fig. 4). In contrast, the overgrazed and shrub encroachment sites displayed a relatively smaller $\mathrm{NEE}_{\text {daytime }}$, but an even smaller relative $R_{\mathrm{e}}$ rate, making these sites net carbon sinks ( $R_{\mathrm{e}} \ll \mathrm{NEE}_{\text {daytime }}$, Fig. 4). Even though both the overgrazed and shrub encroachment sites had $20 \%$ less plant cover and $<\frac{1}{2}$ LAI than the moderate grazing and exclosure sites, they displayed similar or even increased annual net carbon uptake rates, thus rejecting $\mathrm{H}_{1}$.

In these systems, there are several respiring pools (aboveand belowground biomass, deposited litter, and soil microbial biomass) that contributed collectively to $R_{\mathrm{e}}$. Here, we estimated the largest $R_{\mathrm{e}}$ fluxes in the exclosure and moderate grazing sites (Fig. 4), and both also exhibited the largest year-round LAI. If we assume belowground mass similar to that found aboveground, there would be 2- to 10-fold greater root biomass of these two sites compared to the sites with low plant cover, and this could account for the observed 3 to 5 times higher $R_{\mathrm{e}}$ rates. Support for this statement comes from the study by Medina-Roldán et al. (2007) that reported in the same region 2 to 4 times more root biomass in wellpreserved grasslands compared to more open and degraded ones, along a long-term grazing gradient. In this study, root biomass content obtained from the interspaces and under the plants showed up to 10 times more biomass for both high plant cover sites compared to the other sites (Fig. S1, Supplement).

Examination of disturbance frequency in the high plant cover sites offers interesting insights in terms of mechanisms affecting $R_{\mathrm{e}}$ rates. Both sites exhibited more than $30 \%$ basal plant cover, differentiated by the dominance of $B$. gracilis in the exclosure site ( $30 \mathrm{yr}$ of protection from the natural disturbances of grazing and fire) in comparison to a mixed species in the moderate grazing site. Moderate grazing site on the other hand is maintained under a grazing and fire management scheme that facilitates aboveground biomass recovery. Thus, both high cover sites exhibited large accumulation of standing litter (Table 2), which in turn affect both processes 
Table 4. Fitted relationships between daytime and nighttime NEE with leaf area, soil moisture, and air temperature.

\begin{tabular}{lllcc}
\hline Equation & Site & Fitted parameters & $R^{2}$ & $F$ \\
\hline Daytime & & & \\
NEE $=a+b \cdot \mathrm{LAI}$ & Crop & $a=0.6477, b=-0.0009$ & 0.65 & 9.18 \\
& Exclosure & $a=0.5039, b=-3.3852$ & 0.74 & 20.22 \\
& Moderate grazing & $a=0.3240, b=-2.4055$ & 0.56 & 9.02 \\
$\mathrm{NEE}=a+b \cdot \mathrm{LAI}+c \cdot \mathrm{LAI}^{2}$ & Overgrazing & $a=-0.0975, b=3.2000 c=-49.7930$ & 0.67 & 6.11 \\
$\mathrm{NEE}=a+b \cdot \mathrm{SWC}$ & Exclosure & $a=0.3492, b=-0.0636$ & 0.64 & 13.96 \\
& Moderate grazing & $a=0.6333, b=-0.1006$ & 0.67 & 16.42 \\
& Shrub encroachment & $a=0.3849, b=-0.0620$ & 0.47 & 6.16 \\
\hline $\mathrm{Nighttime}$ & & & & \\
$\mathrm{NEE}=a \cdot e^{(b \cdot T)} \cdot \mathrm{SWC}^{c}$ & Crop & $a=0.0693, b=0.00547, c=1.177$ & 0.46 & 86.62 \\
& Exclosure & $a=0.0768, b=0.0125, c=1.0671$ & 0.73 & 266.59 \\
& Moderate grazing & $a=0.0674, b=0.0106, c=1.1794$ & 0.55 & 118.56 \\
& Overgrazing & $a=0.00365, b=0.0399, c=1.623$ & 0.44 & 51.81 \\
& Shrub encroachment & $a=0.026, b=0.0317, c=1.1598$ & 0.68 & 161.12 \\
\hline
\end{tabular}

$\mathrm{LAI}=$ leaf area index, $\mathrm{SWC}=$ soil water content, $T=$ air temperature. All regressions are significant at $\alpha=0.05$.

of dead (increased respiration) and alive (decreased photosynthesis) aboveground biomass, resulting in overall reduced uptake rates. Thus, it is likely that standing litter microbial decomposition was one mechanism contributing to $R_{\mathrm{e}}$. Yet, recent studies also show that photochemically induced $\mathrm{CO}_{2}$ efflux (by UV radiation) could also trigger higher $R_{\mathrm{e}}$ rates (Brandt et al., 2009; Rutledge et al., 2010) with photodegradation of standing litter as another decompositional pathway in arid environments (Vivanco and Austin, 2006; MartínezYrízar et al., 2007; Parton et al., 2007; Henry et al., 2008).

Our data strongly suggest that standing litter attenuates the radiative transfer. Evidence in this study for this included the following: positive NEE fluxes in the late afternoon (data not presented), lower daytime NEE rates at similar PPFD (Fig. 5), and the high light compensation point of high plant cover sites compared to other sites (e.g., overgrazing, Fig. 5a). In the case of the exclosure and moderate grazing (the sites with the most death standing litter, Table 2), our analyses support the contention that large accumulated litter in grasslands can cause (i) additional limitations of PPFD to emergent shoots (up to $58 \%$ less PPFD, Fig. 2b), (ii) a decreased uptake (up to $32 \%$ ) through a reduction of photosynthetic capacity due to modifications in leaf traits (reductions in leaf thickness, specific leaf mass, stomatal density and conductance), and (iii) modifications to the nitrogen cycling (Knapp and Seastedt, 1986). If these sites could recover their natural fire cycles, we could expect not only the large pulse of carbon during fire, but also uptake rates and overall carbon balance to increase as well.

Finally, biological soil crusts (BSCs) are an important component of grasslands especially in those with a large proportion of plant interspaces (like overgrazing and shrub encroachment sites). Photosynthesis and respiration activity in BSCs is also controlled by soil moisture (Cable and Huxman,
2004; Bowling et al., 2011; Lange et al., 1998); thus, during the long drought periods (December to May) BSC activity was not expected in this region.

Estimations of integrated $\mathrm{NEE}_{\text {daytime }}$ and annual NEE balance derived from this study should be taken with caution in case of comparisons of these rates with other ecosystems or when examining their potential roles as sinks or sources of carbon. As indicated in the methods, NEE daytime modeling was carried out considering ideal daily PPFD and eliminating the natural cloud effect, in particular during the growing season. Hence, NEE estimations may show larger carbon uptake rates than actually observed under natural light conditions. This allowed us to cancel out any effects derived from climate variability (PPFD, temperature); further we could examine NEE differences related to changes in plant functional responses (i.e., C3, C4), plant cover and species composition.

\subsection{NEE sensitivity to environmental controls as a function of plant cover}

To test $\mathrm{H}_{2}$, we examined threshold conditions: light compensation points (LCPs), maximum rates of photosynthesis change to increased PPFD, and maximum rates of respiration change to SWC, and $T_{\mathrm{a}}$. Sites with low plant cover and low LAI showed greater sensitivity to increases in PPFD in support of $\mathrm{H}_{2}$. According to this pattern, sites with low plant cover had generally smaller LCPs (from 60 to $348 \mu \mathrm{mol} \mathrm{m}^{-2} \mathrm{~s}^{-1}$ ) compared to sites with high plant cover (151 to $485 \mu \mathrm{mol} \mathrm{m}{ }^{-2} \mathrm{~s}^{-1}$, Table S1, Supplement). Equally, sites with low plant cover had $A_{\max }$ values at lower PPFD than sites with high plant cover (Fig. 5). Overall, sites with low plant cover (and low LAI) are characterized by small plant patches with large open ground interspaces and low stature canopies, all vegetation characteristics that contribute to large canopy radiative transfer and minimum light 
attenuation (low extinction coefficients), enhancing vegetation sensitivity to lower radiation levels. Therefore, vegetation responses such as light compensation point and light saturation NEE are reached sooner compared to communities with high plant cover. This is also supported by the observed greater efficiency of a unit LAI in the net carbon uptake rates, which resulted in 2 times as large when compared to the high plant cover sites $\left(6.75 \mu \mathrm{mol} \mathrm{m}{ }^{-2} \mathrm{~s}^{-1}\right.$ for both overgrazed and shrub encroachment, and 3.39 and $2.4 \mu \mathrm{mol} \mathrm{m}^{-2} \mathrm{~s}^{-1}$ for exclosure and moderate grazed respectively, calculated as the first derivative of a quadratic equation at maximum observed LAI). Although other studies have reported increases in canopy photosynthesis following a growth in LAI (Lai et al., 2002), the efficiency of LAI for carbon uptake would decrease as a function of leaf self-shading and increases in leaf respiration (Lai et al., 2002).

When examining NEE as a function of SWC during the daytime, we only found partial support for $\mathrm{H}_{2}$ (Fig.7). Thus, moderate grazing site displayed the largest rate of change (uptake) per unit \% SWC from all the sites, whereas the exclosure site - with the highest plant cover - showed similar $\mathrm{NEE}_{\text {daytime }}$ rates to sites with low plant cover. We interpreted this result as the combination of several factors: (i) reduced uptake capacity by the exclosure site due to the large amount of aboveground biomass (live and death) limiting PPFD, increasing photodegradation and $R_{\mathrm{e}}$ as mentioned earlier (Brandt et al., 2009; Lai et al., 2011), and (ii) live biomass at the moderate grazing site being stimulated by grazing and fire, i.e., disturbance (Coughenour, 1985).

Seasonal $\mathrm{NEE}_{\text {nighttime }}$ responses to SWC from the low plant cover sites (overgrazed and shrub encroachment) showed lower basal respiration rates ( $a$ term of Eq. 6) than sites with high plant cover (Table 4), in support to $\mathrm{H}_{2}$. We attribute this difference to a combination of (i) lower maintenance costs of smaller biomass $\left(\sim 442 \mathrm{~kg} \mathrm{ha}^{-1}\right.$, Table 1$)$ and (ii) lower inputs to support microbial respiration for the low plant cover sites. Additional explanations for smaller night carbon release in low plant cover sites include higher sensibility to air temperature throughout the year ( $b$ term of Eq. 6 ) and lower capacity to infiltrate and store water in soil (high runoff) (Fig. 2, Medina-Roldán et al., 2008).

Comparison of $Q_{10}$ values to examine $\mathrm{NEE}_{\text {daytime }}$ sensitivity to $T_{\mathrm{a}}$ from sites with low plant cover showed similar $Q_{10}$ values among most sites (2.09-2.88). This result was observed in spite of lower estimates of temperature sensitivity because of using air temperature instead of soil temperature (Lasslop et al., 2012). Still, they span the mean value of 2.4 reported for soil respiration in terrestrial ecosystems (Raich and Schlesinger, 1992). The exception was observed for the shrub encroachment site that showed a $Q_{10}$ twice as large as those for the overgrazed site (4.39 vs. 2.89 for March and May, respectively). In the shrub encroachment site, $C_{3}$ forbs and subshrubs were the dominant functional group, characterized by expressing larger daytime respiration sensibility to elevated temperatures (cf. Fig. 6, March and May
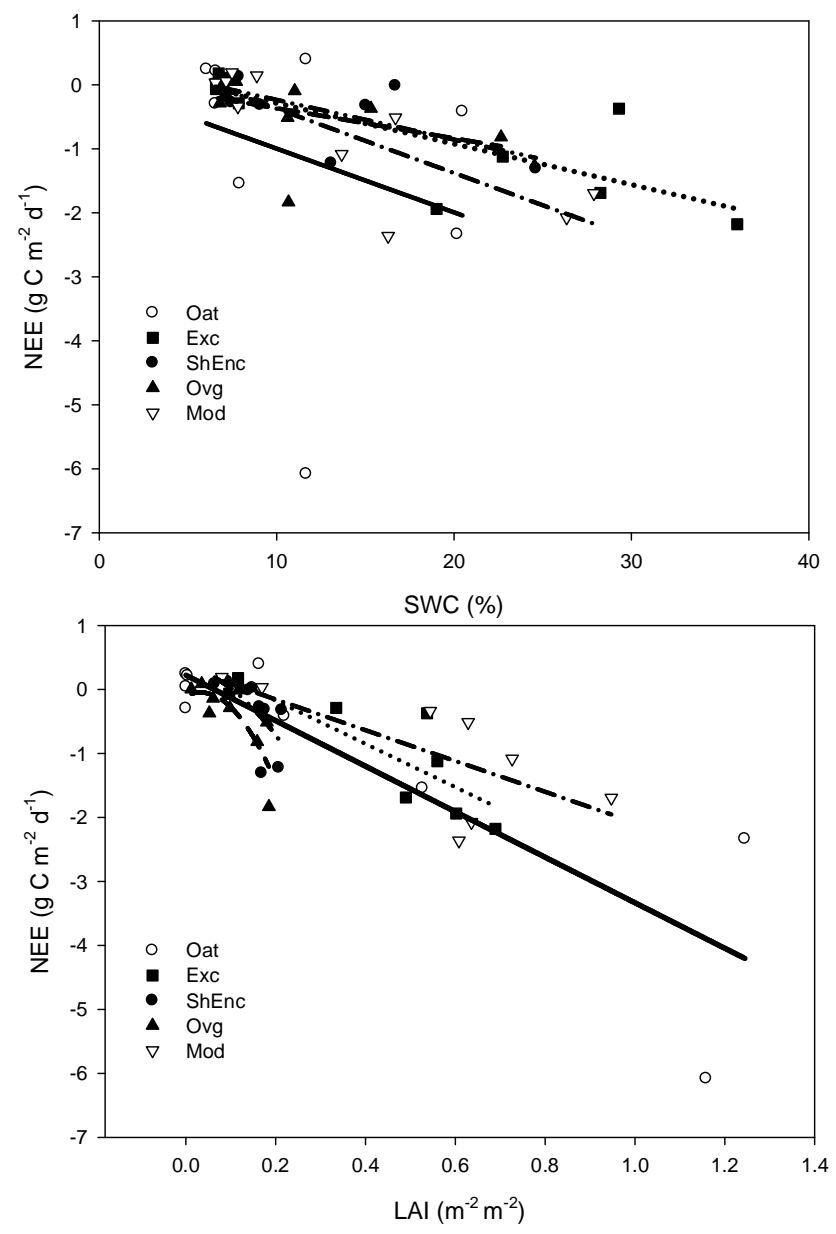

Fig. 7. (a) Linear regressions between daily daytime NEE and SWC in five contrasting land use change types measured during ten months. (b) Linear regressions between daily daytime NEE and LAI. Line symbols correspond to the following: $\cdots$ Exc, $-\cdot-$ Mod, -- Ovg, $-\cdot \cdot-$ ShEnc, and — Crop. For explanations of abbreviations, refer to Fig. 2.

(Lambers et al., 1998)). Seasonal patterns of plant activity, i.e., phenology (Gebremedhinet al., 2012; Curiel Yuste et al., 2004), can also induce differences in $Q_{10}$. In this regard, the shrub encroachment, a $\mathrm{C}_{3}$-dominant functional group, showed photosynthetically active leaves and stems between March and May, whereas the overgrazed $\mathrm{C}_{4}$ functional group was dormant (senescent) in this season (Fig. 6). For daily light response curves from the moderate grazing site, we also observed a hysteresis-like loop controlled by $T_{\mathrm{a}}$ (data not shown) suggesting an increase in $R_{\mathrm{e}}$ in the afternoon during the warmer hours, similar to the one reported by Gilmanov et al. (2010). Vegetation at the moderate grazing site included a dense cover of annual $C_{3}$ herbs that emerged following early rains in summer. Thus, differences in the degree of control by environmental factors on NEE fluxes between grassland communities emerged from seasonal changes in the preponderance of plant functional groups $\left(\mathrm{C}_{3}\right.$ vs. $\mathrm{C}_{4}$ species). This 
hysteresis-like loop response was equally observed for the crop site dominated by oat, a $\mathrm{C}_{3}$ species.

\subsection{NEE as a function of species composition}

In agreement with $\mathrm{H}_{3}$, differential effects on NEE fluxes as well as on NEE sensitivity to controlling factors were mediated by plant cover with no clear effects of vegetation species composition. For example, exclosure and moderate grazing sites displayed very similar NEE rates for both dayand nighttime (Figs. 3, 4). For low plant cover plots, there were statistically no differences in net NEE. Still, the overgrazed site exhibited half the $\mathrm{CO}_{2}$ efflux compared to the shrub encroachment site (Fig. 4). The two-fold difference in $\mathrm{NEE}_{\text {nighttime }}$ rates observed in the shrub encroachment site with dominant $C_{3}$ native subshrubs and exotic perennials may have resulted from a larger aboveground biomass (442 $\mathrm{kg} \mathrm{ha}^{-1}, 2$ times larger than in the overgrazed site), higher respiration costs from year-long maintenance of an evergreen canopy including adaptations to withstand harsh environmental factors and resistance to herbivory (Wardle et al., 1998; Díaz et al., 2007), and larger temperature sensitivity by $\mathrm{C}_{3}$ plants in their autotrophic respiration.

Finally, the crop site, characterized by a uniform plant cover and an architecture that includes enough spacing among plants as well as erectophile leaves, is more efficient at reducing shading and optimizing photosynthesis per unit leaf area. This feature, together with a low belowground biomass typical of an annual species, produced the largest net $\mathrm{C}$ uptake rates among the five sites (Fig. 4). Net $\mathrm{C}$ uptake rates observed in the crop site should be taken with caution since most biomass is removed from the site at harvest and decomposed somewhere else. Therefore $\mathrm{CO}_{2}$ emissions from exported biomass are not accounted in this NEE study (or in other studies).

\section{Conclusions}

Site differences in plant cover caused by contrasting land use influenced patterns of net carbon uptake. A combination of factors such as plant cover, accumulated litter and aboveground live biomass (LAI), species predominance in the vegetation and the balance between NEE and $R_{\mathrm{e}}$ contributed to the final $\mathrm{C}$ budget of the different plant communities. Thus, the overgrazed site with low respiratory fluxes resulted in the greatest net $\mathrm{C}$ sink compared to the exclosure, the moderate grazed, and the crop sites, in spite of its low plant cover $(<10 \%)$. Plant cover showed some influences on NEE drivers mostly due to its associated LAI and accumulated biomass. These influences on NEE operated throughout PPFD attenuation and decoupling of vegetation temperature. Finally, no clear influences on NEE were attributed to grassland species composition. Still, seasonal emergence or dominance of functional groups in which $\mathrm{C}_{3}$ herbs, subshrubs and exotic species prevailed over native $\mathrm{C}_{4}$ grasses may account for important net NEE differences.

Our results contribute to an improved understanding of patchy landscapes, such as the shortgrass steppe from central Mexico - for the management of carbon resources. Where biomass harvest is the primary benefit, management should incorporate criteria to optimize biomass harvest (e.g., oat crop, cattle grazing) combined with the maximum capability to store carbon at larger spatial scales. This could be particularly important for converted fields to rainfed agriculture from the semiarid region of central Mexico, which contributes a neutral or even a carbon sink regionally.

\section{Supplementary material related to this article is available online at: http://www.biogeosciences.net/10/ 4673/2013/bg-10-4673-2013-supplement.pdf.}

Acknowledgements. We thank INIFAP (Sitio Experimental Vaquerias) for allowing the use of their facilities to carry out this study. We thank Paul Duffy for comments and recommendations on a previous version. Also, J. Delgado-Balbuena thanks CONACYT for the scholarship (ref. no. 070278) for his M.S. studies. This research was funded by SEMARNAT-CONACYT (ref. no. 108000), granted to J. T. Arredondo. Partial funding for publication was also granted from SEP-CONACYT (ref. no. 102855). H. W. Loescher acknowledges National Science Foundation (EF-102980) for ongoing support. The National Ecological Observatory Network is a project sponsored by the NSF and managed under cooperative agreement by NEON, Inc. Any opinions, findings, and conclusions or recommendations expressed in this material are those of the authors and do not necessarily reflect the views of the NSF. We thank Don Julio for inspiring many late night scientific discussions.

Edited by: M. Bahn

\section{References}

Aguado-Santacruz, G. A.: Efecto de factores ambientales sobre la dinámica vegetacional en pastizales de los Llanos de Ojuelos, Jalisco: un enfoque multivariable, MSc, Colegio de Postgraduados, Chapingo, México, 1993.

Aguado-Santacruz, G. A. and Garcia-Moya,E.: Environmental factors and community dynamics at the southernmost part of the North American Graminetum - I. On the contribution of climatic factors to temporal variation in species composition, Plant Ecol., 135, 13-29, doi:10.1023/A:1009750831162, 1998.

Alluvione, F., Halvorson, A. D., and Del Grosso, S. J.: Nitrogen, tillage, and crop rotation effects on carbon dioxide and methane fluxes from irrigated cropping systems, J. Environ. Qual., 38, 2023-2033, doi:10.2134/jeq2008.0517, 2009.

Arnone, J. A. and Obrist, D.: A large daylight geodesic dome for quantification of whole-ecosystem $\mathrm{CO} 2$ and water vapour fluxes in arid shrublands, J. Arid Environ., 55, 629-643, doi:10.1016/S0140-1963(02)00291-4, 2003. 
Belsky, A. J.: Effects of Grazing, Competition, Disturbance and Fire on Species Composition and Diversity in Grassland Communities, J. Veg. Sci., 3, 187-200,1992.

Bowling, D. R., Grote, E. E., and Belnap, J.: Rain pulse response of soil $\mathrm{CO}_{2}$ exchange by biological soil crusts and grasslands of the semiarid Colorado Plateau, United States, J. Geophys. Res., 116, G03028, doi:10.1029/2011JG001643, 2011.

Brandt, L. A., Bohnet, C., and King, J. Y.: Photochemically induced carbon dioxide production as a mechanism for carbon loss from plant litter in arid ecosystems, J. Geophys. Res., Vol. 114, G02004, doi:10.1029/2008JG000772, 2009.

Brown, J. R. and Archer, S.: Shrub invasion of grassland: Recruitment is continuous and not regulated by herbaceous biomass or density, Ecology, 80, 2385-2396, 1999.

Cable, J. and Huxman, T.: Precipitation pulse size effects on Sonoran Desert soil microbial crusts, Oecologia, 141, 317-324, doi:10.1007/s00442-003-1461-7, 2003.

Canfield, R. H.: Application of the line interception method in sampling range vegetation, J. Forest., 39, 388-394, 1941.

Chapin, F. S., Matson, P. A., and Vitousek, P. M.: Principles of Terrestrial Ecosystem Ecology, 1st Edn., Springer Verlag, New York, 2002.

Chapin, F. S., Randerson, J. T., McGuire, A. D., Foley, J. A., and Field, C. B.: Changing feedbacks in the climate-biosphere system, Front. Ecol. Environ., 6, 313-320, 2008.

COTECOCA (Comité Técnico Consultivo de Coeficientes de Agostaderos).: Coeficientes de agostadero de la República Mexicana. Estado de Jalisco, SARH-Subsecretaría de Ganadería, México, 1979.

Coughenour, M. B.: Graminoid responses to grazing by large herbivores: adaptation, exaptation, and interacting processes, Ann. Missouri Bot. Garden, 72, 852-863, 1985.

Crider, F. J.: Root-growth stoppage resulting from defoliation of grass, US Dept. of Agriculture, 1955.

Curiel Yuste, J., Janssens, I. A., Carrara, A., and Ceulemans, R.: Annual $Q_{10}$ of soil respiration reflects plant phenological patterns as well as temperature sensitivity, Glob. Change Biol., 10, 161-169, 2004.

Davidson, E. A., Savage, K., Verchot, L. V., and Navarro, R.: Minimizing artifacts and biases in chamber-based measurements of soil respiration, Agr. Forest Meteorol., 113, 21-37, 2002.

DeFries, R. S., Field, C. B., Fung, I., Collatz, G. J., and Bounoua, L.: Combining satellite data and biogeochemical models to estimate global effects of human-induced land cover change on carbon emissions and primary productivity, Global Biogeochem. Cy., 13, 803-815, 1999.

Dewar, R. C., Medlyn, B. E., and Mcmurtrie, R. E.: Acclimation of the respiration/photosynthesis ratio to temperature: insights from a model, Glob. Change Biol., 5, 615-622, doi:10.1046/j.13652486.1999.00253.x, 1999.

Dewar, R. C.: A model of the coupling between respiration, active processes and passive transport, Ann. Bot.-London, 86, 279-286, 2000.

Díaz, S., Lavorel, S., Mcintyre, S., Falczuk, V., Casanoves, F., Milchunas, D. G., Skarpe, C., Rusch, G., Sternberg, M., NoyMeir, I., Landsberg, J., Zhang, W., Clark, H., and Campbell, B. D.: Plant trait responses to grazing - a global synthesis, Glob. Change Biol., 13, 313-341, 2007.
García, E.: Distribución de la precipitación en la República Mexicana, Boletín del Instituto de Geografía, UNAM, 50, 67-76, 2003.

García-Moya, E. and Villa, J.: Factores que afectan la distribución geográfica y ecológica de Bouteloua gracilis (H.B.K.) Lag ex Steud, en el estado de San Luis Potosí, Agrociencia, 28, 3-39, 1977.

Gebremedhin, M. T., Loescher, H. W., and Tsegaye, T.: Net ecosystem carbon dioxide exchange over a rainfed double cropping agroecosystem in Northern Alabama, Agronomy J. 104, 1321$1335,2012$.

Gilmanov, T. G., Aires, L., Barcza, Z., Baron, V. S., Belelli, L., Beringer, J., Billesbach, D., Bonal, D., Bradford, J., Ceschia, E., Cook, D., Corradi, C., Frank, A., Gianelle, D., Gimeno, C., Gruenwald, T., Guo, H., Hanan, N., Haszpra, L., Heilman, J., Jacobs, A., Jones, M. B., Johnson, D. A., Kiely, G., Li, S., Magliulo, V., Moors, E., Nagy, Z., Nasyrov, M., Owensby, C., Pinter, K., Pio, C., Reichstein, M., Sanz, M. J., Scott, R., Soussana, J. F., Stoy, P. C., Svejcar, T., Tuba, Z., and Zhou, G.: Productivity, respiration, and light-response parameters of world grassland and agroecosystems derived from flux-tower measurements, Rangeland Ecol. Manag., 63, 16-39, 2010.

Harpole, W. S., Potts, D. L., and Suding, K. N.: Ecosystem responses to water and nitrogen amendment in a California grassland, Glob. Change Biol., 13, 2341-2348, doi:10.1111/j.13652486.2007.01447.x, 2007.

Hart, R. H.: Land-Use history on the shortgrass steppe, in: Ecology of the shortgrass steppe, a long-term perspective, edited by: Lauenroth, W. K. and Burke, I. C., Oxford University Press LTER, 55-69, 2008.

Henry, H. A. L., Brizgys, K., and Field, C. B.: Interactive effects of fire, elevated carbon dioxide, nitrogen deposition, and precipitation on a California Annual Grassland, Ecosystems 11, 545-554, 2008.

Houghton, R. and Goodale, C.: Effects of land-use change on the carbon balance of terrestrial ecosystems, in Ecosystems and Land Use Change, in: Geophys. Monogr. Ser., edited by:. DeFries, R. S, Asner, G. P., and Houghton, R. A., AGU, Washington, DC, 153, 85-98, doi:10.1029/153GM08, 2004.

Huber-Sannwald, E.: Land use change and biodiversity: A local or global issue, Primer foro ambiental del Departamento de Ingeniería Ambiental y Manejo de Recursos Naturales - IPICYT, 1, 110-117, 2002.

Huggins, D. R., Buyanovsky, G. A., Wagner, G. H., Brown, J. R., Darmody, R. G., Peck, T. R., Lesoing, G. W., Vanotti, M. B., and Bundy, L. G.: Soil organic $\mathrm{C}$ in the tallgrass prairie-derived region of the corn belt: effects of long-term crop management, Soil Till. Res., 47, 219-234, doi:10.1016/S0167-1987(98)00108$1,1998$.

ISO (International Organization for Standardization): Evaluation of measurement data - Guide to the expression of uncertainty in measurement, International Organization for Standardization, Geneva, Switzerland, 132 pp., 2008.

Jasoni, R. L., Smith, S. D., and Arnone, J. A.: Net ecosystem $\mathrm{CO}_{2}$ exchange in Mojave Desert shrublands during the eighth year of exposure to elevated $\mathrm{CO}_{2}$, Glob. Change Biol., 11, 749-756, 2005.

Knapp, A. K. and Seastedt, T. R.: Detritus accumulation limits productivity of tallgrass prairie, BioScience, 36, 662-668, 1986. 
Knapp, A. K., Blair, J. M., Briggs, J. M., Collins, S. L., Hartnett, D. C., Johnson, L. C., and Towne E. G.: The keystone role of bison in North American tallgrass prairie, BioScience, 49, 3950, 1999.

Lai, C. T., Katul, G., Butnor, J., Siqueira, M., ellsworth, D., Maier, C., Johnsen, K., Mckeand, S., and Oren, R.: Modelling the limits on the response of net carbon exchange to fertilization in a southeastern pine forest, Plant Cell Environ., 25, 1095-1119, 2002.

Lal, R.: Carbon sequestration in dryland ecosystems, Environ. Manage., 33, 528-544, doi:10.1007/s00267-003-9110-9, 2004.

Lambers, H., Chapin, F. S., and Pons, T. L.: Plant physiological Ecology, 2nd Edn., Springer New York, New York, 2008.

Lange, O. L., Belnap, J., and Reichenberger, H.: Photosynthesis of the cyanobacterial soil-crust lichen Collema tenax from arid lands in southern Utah, USA: role of water content on light and temperature responses of CO2 exchange, Funct. Ecol., 12, 195202, doi:doi:10.1046/j.1365-2435.1998.00192.x, 1998.

Lasslop, G., Migliavacca, M., Bohrer, G., Reichstein, M., Bahn, M., Ibrom, A., Jacobs, C., Kolari, P., Papale, D., Vesala, T., Wohlfahrt, G., and Cescatti, A.: On the choice of the driving temperature for eddy-covariance carbon dioxide flux partitioning, Biogeosciences, 9, 5243-5259, doi:10.5194/bg-9-52432012, 2012.

Levy, P., Friend, A., White, A., and Cannell, M.: The influence of land use change on global-scale fluxes of carbon from terrestrial ecosystems, Climatic Change, 67, 185-209, doi:10.1007/s10584-004-2849-z, 2004.

Lindroth, A., Lagergren, F., Aurela, M., Bjarnadottir, B., Christensen, T., Dellwik, E., Grelle, A., Ibrom, A., Johansson, T., Lankreijer, H., Launiainen, S., Laurila, T., Mölder, M., Nikinmaa, E., Pilegaard, K., Sigurdsson, B. D., and Vesala, T.: Leaf area index is the principal scaling parameter for both gross photosynthesis and ecosystem respiration of Northern deciduous and coniferous forests, Tellus B, 60, 129-142, 2008.

Livingston, G. P. and Hutchinson G. L.: Enclosure-based measurement of trace gas exchange: Applications and sources of error, in: Biogenic Trace Gases: Measuring Emissions from Soil and Water, edited by: Matson, P. A. and Harriss, R. C., Blackwell Sci. Ltd., London, 14-51, 1995.

Loescher, H. W., Law, B. E., Mahrt, L., Hollinger, D. Y., Campbell, J. L. and Wofsy S. C.: Uncertainties in- and interpretation of carbon flux estimates using the eddy covariance technique. J. Geophys. Res.-Atmos, 111, D21S90, doi:10.1029/2005JD006932, 2006a.

Loescher, H. W., Starr, G., Martin, T. A., Binford, M., and Gholz, H. L.: The effect of local atmospheric circulations on daytime carbon dioxide flux measurements over a Pinus elliottii canopy, J. Appl Meteorol. Clim., 45, 1127-1140, 2006b.

Martinez-Yrizar, A.: Leaf litter decomposition in a southern Sonoran Desert ecosystem, northwestern Mexico: Effects of habitat and litter quality, Acta Oecol., 32, 291-300, 2007.

Medina-Roldán, E., Arredondo Moreno, J. T., García Moya, E., and Huerta Martínez, F. M.: Soil water content dynamics along a range condition gradient in a shortgrass steppe, Rangeland Ecol. Manag., 60, 79-87, doi:10.2111/05-219R2.1, 2007.

Medina-Roldán, E., Arredondo, J., Huber-Sannwald, E., ChapaVargas, L. and Olalde-Portugal V.: Grazing effects on fungal root symbionts and carbon and nitrogen storage in a shortgrass steppe in Central Mexico, J. Arid Environ., 72, 546-556, doi:10.1016/j.jaridenv.2007.07.005, 2008.

Milchunas, D. G. and Lauenroth, W. K.: Quantitative effects of grazing on vegetation and soils over a global range of environments, Ecol. Monogr., 63, 327-366, 1993.

Novick, K. A., Stoy, P. C., Katul, G. G., Ellsworth, D. S., Siqueira, M. B. S., Juang, J., and Oren, R.: Carbon dioxide and water vapor exchange in a warm temperate grassland, Oecologia, 138, 259274, doi:10.1007/s00442-003-1388-z, 2004.

Noy-Meir, I.: Interactive effects of fire and grazing on structure and diversity of mediterranean grasslands, J. Veg. Sci., 6, 701-710, 1995.

Parton, W., Silver, W. L., Burke, I. C., Grassens, I., Harmon, M. E., Currie, W. S., King, J. Y., Adair, E. C., Brandt, L. A., Hart, S. C., and Fasth, B.: Global-scale similarities in nitrogen release patterns during long-term decomposition, Science, 315, 361-364, 2007.

Raich, J. W. and Schlesinger, W. H.: The global carbon dioxide flux in soil respiration and its relationship to vegetation and climate, Tellus B, 44, 81-99, 1992.

Richards, J. H. and Caldwell, M. M.: Soluble carbohydrates, concurrent photosynthesis and efficiency in regrowth following defoliation: a field study with Agropyron species, J. Appl. Ecol., 22, 907-920, 1985.

Riojas-Lopez, M. and Mellink, E.: Potential for biological conservation in man-modified semiarid habitats in northeastern Jalisco, Mexico, Biodivers. Conserv., 14, 2251-2263, 2005.

Ruimy, A., Jarvis, P. G., Baldocchi, D. D., and Saugier, B.: $\mathrm{CO}_{2}$ fluxes over plant canopies and solar radiation: A review, Adv. Ecol. Res., 26, 1-68, 1995.

Rutledge, S., Campbell, D. I., Baldocchi, D., and Schipper, L. A.: Photodegradation leads to increased carbon dioxide losses from terrestrial organic matter, Glob. Change Biol., 16, 3065-3074, doi:10.1111/j.1365-2486.2009.02149.x, 2010.

Rzedowski, J.: Vegetación de México, 1st Edn., Comisión Nacional para el Conocimiento y Uso de la Biodiversidad, México, http://www.conabio.gob.mx/institucion/centrodoc/ doctos/vegetacion_de_mexico.html, 2006.

Scott, R. L., Huxman, T. E., Williams, D. G., and Goodrich D. C.: Ecohydrological impacts of woody-plant encroachment: seasonal patterns of water and carbon dioxide exchange within a semiarid riparian environment, Glob. Change Biol., 12, 311-324, 2006.

Starr, G., Staudhammer, C. L., Loescher, H. W., Mitchell, R., Whelan, A., McGee, J., Hiers, J. K., and O'Brien, J. J.: Fire's role in Longleaf pine forest carbon dynamics: Evidence of resiliency in physiological estimates following prescribed fire, Agr. Forest Meteorol., in review, 2013.

Vargas, R., Baldocchi, D. D., Bahn, M., Hanson, P. J., Hosman, K. P., Kulmala, L., Pumpanen, J., and Yang, B.: On the multitemporal correlation between photosynthesis and soil $\mathrm{CO}_{2}$ efflux: reconciling lags and observations, New Phytol., 191, 10061017, doi:10.1111/j.1469-8137.2011.03771.x, 2011.

Velázquez, A., Mas, J. F., Díaz-Gallegos, J. R., Mayorga-Saucedo, R., Alcántara, P. C., Castro, R., Fernández, T., Bocco, G., and Ezcurra, E.: Patrones y tasas de cambio de uso del suelo en México, Gaceta Ecológica, 062, 21-37, 2002.

Vivanco, L. and Austin, A.: Intrinsic effects of species on leaf litter and root decomposition: a comparison of temperate grasses from North and South America, Oecologia, 150, 97-107, 2006. 
Wardle, D. A., Barker, G. M., Bonner, K. I., and Nicholson, K. S.: Can comparative approaches based on plant ecophysiological traits predict the nature of biotic interactions and individual plant species effects in ecosystems?, J. Ecol., 86, 405-420, 1998.

Whitehead, D., Griffin, K. L., Turnbull, M. H., Tissue, D. T., Engel, V. C., Brown K. J., Schuster, W. S. F., and Walcroft, A. S.: Response of total night-time respiration to differences in total daily photosynthesis for leaves in Quercus rubra L. canopy: implications for modeling canopy $\mathrm{CO}_{2}$ exchange, Glob. Change Biol., 10, 925-938, 2004.

Wohlfahrt, G., Hammerle, A., Haslwanter, A., Bahn, M., Tappeiner, U., and Cernusca, A.: Seasonal and inter-annual variability of the net ecosystem $\mathrm{CO}_{2}$ exchange of a temperate mountain grassland: Effects of weather and management, J. Geophys. Res., 113, D08110, doi:10.1029/2007JD009286, 2008a.
Wohlfahrt, G., Fenstermaker, L. F., and Arnone III, J. A.: Large annual net ecosystem $\mathrm{CO}_{2}$ uptake of a Mojave Desert ecosystem, Glob. Change Biol., 14, 1475-1487, 2008b.

Xue-Fa, W., Gui-Rui, Y., Xiao-Min, S., Qing-Kang, L., Yun-Fen, L., Lei-Ming, Z., Chuan-You, R., Yu-Ling, F., and Zheng-Quan, L.: Soil moisture effect on the temperature dependence of ecosystem respiration in a subtropical Pinus plantation of shoutheastern China, Agr. Forest Meteorol., 137, 166-175, 2006. 